\title{
Short-term variability in bacterial abundance, cell properties, and incorporation of leucine and thymidine in subarctic sea ice
}

\author{
H. Kaartokallio 1,* , D. H. Søgaard ${ }^{2,3}$, L. Norman ${ }^{4}$, S. Rysgaard ${ }^{2,5,6}$, \\ J.-L. Tison ${ }^{7}$, B. Delille ${ }^{8}$, D. N. Thomas ${ }^{1,4,5}$ \\ ${ }^{1}$ Marine Research Center, Finnish Environment Institute, Erik Palmenin aukio 1 00560, Helsinki, Finland \\ ${ }^{2}$ Greenland Climate Research Centre, c/o Greenland Institute of Natural Resources, Kivioq 2, Nuuk 3900, Greenland \\ ${ }^{3}$ University of Southern Denmark, Campusvej 55, 5230 Odense M, Denmark \\ ${ }^{4}$ School of Ocean Sciences, Bangor University, Menai Bridge, Anglesey LL59 5AB, UK \\ ${ }^{5}$ Arctic Research Centre, Aarhus University, C.F. Møllers Allé 8, Bldg. 1110, 8000 Aarhus C, Denmark \\ ${ }^{6}$ Centre for Earth Observation Science, 535 Wallace Building, University of Manitoba, Winnipeg R3T 2N2, Canada \\ ${ }^{7}$ Glaciology Unit, Department of Earth and Environmental Science, Université Libre de Bruxelles, ULB CP 160/03 50 Avenue \\ F. D. Roosevelt, 1050 Bruxelles, Belgium \\ ${ }^{8}$ Unité d'Océanographie Chimique, MARE, Université de Liège, Allée du 6 Août, 17-4000 Liège, Belgium
}

\begin{abstract}
Sea ice is a biome of immense size and provides a range of habitats for diverse microbial communities, many of which are adapted to living at low temperatures and high salinities in brines. We measured simultaneous incorporation of thymidine (TdR) and leucine (Leu), bacterial cell abundance and cell population properties (by flow cytometry) in subarctic sea ice in SW Greenland. Short-term temporal variability was moderate, and steep environmental gradients, typical for sea ice, were the main drivers of the variability in bacterial cell properties and activity. Low nucleic acid (LNA) bacteria, previously linked to oligotrophic ecotypes in marine habitats, were more abundant in the upper ice layers, whereas high nucleic acid (HNA) bacteria dominated in lower ice, where organic carbon was in high concentrations. Leu incorporation was saturated at micromolar concentrations, as known from freshwater and marine biofilm systems. Leu:TdR ratios were high (up to >300) in lowermost ice layers, and when compared to published respiration measurements, these results suggest non-specific Leu incorporation. There was evidence of polyhydroxyalkanoate (PHA)-containing bacteria in the sea ice, shown by brightly fluorescing intracellular inclusions after Nile Blue A staining. High Leu saturating concentrations coupled with the occurrence of PHA-producing organisms further highlight the similarity of sea ice internal habitats to biofilm-like systems rather than to open-water systems.
\end{abstract}

KEY WORDS: Sea ice $\cdot$ Bacteria $\cdot$ Temporal variability $\cdot$ Leucine $\cdot$ Thymidine $\cdot$ Flow cytometry Polyhydroxyalkanoates

Resale or republication not permitted without written consent of the publisher

\section{INTRODUCTION}

Sea ice is a defining feature of the marine ecosystems of polar and some subarctic seas, and is an ephemeral biome of immense size comparable to the world's deserts or grasslands (Thomas \& Dieckmann
2002, 2010). Sea ice has characteristically strong and highly variable gradients in temperature, salinity, space and light that are ultimately governed by air temperature and depth of snow cover (Thomas \& Dieckmann 2002). The internal sea ice habitat, i.e. small pores and channels filled with hyper-saline 
brines, can be thought of as resembling biofilm-like systems due to the high densities of organisms and large amounts of exopolymeric substances (EPS) produced by both sea ice algae and bacteria (Krembs \& Deming 2008, Underwood et al. 2010, 2013, Krembs et al. 2011). It is also an extreme habitat since salinity varies as a function of ice temperature and can exceed 200, and the temperature is constantly below seawater freezing temperature, reaching down to $-30^{\circ} \mathrm{C}$ in the uppermost parts of the ice on occasions (Petrich \& Eicken 2010).

Heterotrophic bacteria are the most abundant organism group in ice and important in terms of carbon cycling and biodiversity. The typical bacteria found in sea ice in all ice-covered marine waters belong to the Bacteroidetes (e.g. Flavobacteria) as well as Alpha- and Gammaproteobacteria, although other bacterial groups are also found (Deming 2010). Dissolved organic carbon and nitrogen resources are generally thought to be non-limiting for bacteria in sea ice (Pomeroy \& Wiebe 2001, Thomas et al. 2010). Many of the sea ice bacteria are copiotrophs, and up to $60 \%$ of them can be cultured (Junge et al. 2002).

Generally marine bacteria can be divided into high nucleic acid (HNA) bacteria and low nucleic acid (LNA) bacteria based on their DNA content detected by flow cytometry, and also related to cell size (Gasol \& del Giorgio 2000, Lebaron et al. 2001). Bacteria in sea ice have been enumerated by flow cytometry (Fransson et al. 2011, Martin et al. 2011, Mundy et al. 2011), although the proportions of HNA and LNA populations in the total bacterial abundance have not been reported. HNA bacteria are often attributed to the dynamic part of the bacterial community that is able to respond to changes in nutrient and carbon availability (Morán et al. 2007), whereas abundance of LNA bacteria is generally linked to oligotrophic ecotypes in both freshwater and marine environments (Mary et al. 2006, Wang et al. 2009). In sea ice, algal and bacterial biomass is often concentrated in lower ice layers, and HNA and LNA bacteria can be expected to exist in different proportions in different horizons of the ice; for example, Collins et al. (2010) found dominance of SAR11 cluster bacteria in upper horizons of winter Arctic sea ice, a group whose single cultivated member is an obligate oligotroph (Rappé et al. 2002).

Since the late 1980s, bacterial production in sea ice has been measured, to our knowledge, in less than 15 studies in both polar oceans and the Baltic Sea. These have primarily used thymidine (TdR, Fuhrman \& Azam 1980, 1982) or leucine (Leu, Kirchman et al. 1985) incorporation methods, both widely utilized in aquatic studies. TdR and Leu methods are based on biochemical theory allowing incorporation of radiochemical tracer by DNA (TdR) or protein (Leu) synthesis to be extrapolated into bacterial cell or biomass growth. Bacterial production measurements in sea ice have mostly been made on melted ice samples (e.g. Smith \& Clement 1990, Mock et al. 1997, Søgaard et al. 2010), brines extracted from ice cores or ice cube/crush slurries (e.g. Kottmeier et al. 1987, Helmke \& Weyland 1995, Kaartokallio 2004). Normally only one of the incorporation methods has been applied, and measurements combining both tracers are limited to the Antarctic (Grossmann \& Dieckmann 1994) and Baltic Sea ice (Mock et al. 1997, Kaartokallio et al. 2006, 2008, Kuosa \& Kaartokallio 2006). To our knowledge, dual-labeling has never been done in Arctic or subarctic sea ice investigations. Previous studies in polar and sub-polar sea ice have mostly used only one tracer or revealed conflicting or unclear patterns of Leu and TdR incorporation (Grossmann \& Dieckmann 1994, Helmke \& Weyland 1995, Guglielmo et al. 2000, Pusceddu et al. 2008)

The aim of this paper was to study short-term temporal variability in ice bacterial abundance, cell properties and production with particular emphasis on use of both Leu and TdR methods and the saturation kinetics of the tracers employed. We also applied flow cytometry to study nucleic acid content and apparent size of bacterial cells.

\section{MATERIALS AND METHODS}

\section{Sampling}

Sampling was conducted from 11 to 15 March 2010 in first-year land fast ice in a small fjord belonging to Kangerluat fjord system in SW Greenland, close to the Kapisillit settlement $\left(64^{\circ} 26^{\prime} \mathrm{N}, 50^{\circ} 13^{\prime} \mathrm{W}\right)$. Further details are given by Long et al. (2012) and Søgaard et al. (2013). Sampling was done over 5 consecutive days at the same sampling site (within $10 \mathrm{~m}^{2}$ ), situated approximately $100 \mathrm{~m}$ from the fast ice edge. The water depth at the sampling site was $42 \mathrm{~m}$. The sea ice thickness was $64 \mathrm{~cm}$ and snow thickness was $2 \mathrm{~cm}$ over the entire study period.

On each sampling occasion, 2 to 4 ice cores were retrieved within an area of $0.5 \mathrm{~m}^{2}$ with a Kovacs MARK II CRREL-type core auger. The first core was used for determination of bacterial activity, cell counts and population characteristics. The second was used for salinity, dissolved organic matter (DOM) and inorganic nutrient determinations. The 
remaining cores were used for more detailed salinity, temperature and brine volume profile determination. For investigation of small-scale variability, 5 separate $10 \mathrm{~cm}$ ice top sections were retrieved on each sampling day and analyzed in the same way as the second core above. The first 2 cores were sectioned using a stainless steel hand saw within minutes from retrieval. As biomass is typically concentrated in the lowermost centimeters of ice, a $4 \mathrm{~cm}$ section was cut from the bottom, and the remaining core was divided into $12 \mathrm{~cm}$ sections. Ice sections were put into $1 \mathrm{l}$ plastic pots and transported to the laboratory.

Bacterial production was measured immediately after sampling using crushed ice, for the other variables, samples were processed after complete melting in a cool laboratory deck. Direct melting was used for all ice samples. Water samples were obtained immediately below the ice and, on Days 3 and 5, also from $9 \mathrm{~m}$ under the ice using a peristaltic pump (Cole-Palmer, Master Flex, E/P) with trace metal-free tygon tubing.

To construct detailed ice temperature, salinity and brine volume profiles, temperature and salinity were measured on Days 1, 3 and 5 with a $4 \mathrm{~cm}$ depth resolution. Temperature was measured, in situ, directly after extraction of the cores, using a calibrated probe (Testo 720) inserted in pre-drilled holes (perpendicular to core side) at the exact diameter of the probe and with a depth resolution of $4 \mathrm{~cm}$. The precision of the measurements was $\pm 0.1^{\circ} \mathrm{C}$. Bulk ice salinity measurements were centered on the temperature probe measurements. The temperature core was immediately sliced in the field and stored in polyethylene containers, and left to melt in the laboratory. Salinities were measured after melting at room temperature, with a portable salinometer (Orion Star Series Meter) with a precision of \pm 0.1 .

To get additional information on bacteria moving with the brine in the ice, brines were collected by coring sackholes at about 40 (sackhole 1) and 50 (sackhole 2) cm depth, to allow gravity-driven brine collection (Thomas \& Dieckmann 2010). Brines were collected after 15 to $45 \mathrm{~min}$ (depending on the rate of percolation into the hole) using the portable peristaltic pump described above for temperature, salinity and further measurements.

The theoretical brine volume fraction $\left(V_{\mathrm{b}} / V\right.$, Eq. 1) and brine salinity $\left(S_{\mathrm{b}}\right.$, Eq. 2$)$ are calculated from ice temperature $(T)$ and bulk ice salinity $(S)$ using the formulae of Petrich \& Eicken (2010), neglecting the air volume fraction $\left(V_{\mathrm{a}} / V\right)$ and using the coefficients $\mathrm{F} 1(T)$ and F2(T) from Cox \& Weeks (1983) to define 2 empirical functions related to the temperature. $\rho_{\mathrm{i}}$ and $S_{\mathrm{i}}$ are pure ice density and bulk ice salinity respectively.

$$
\begin{gathered}
V_{\mathrm{b}} / V=\left(1-V_{\mathrm{a}} / V\right)\left(\rho_{\mathrm{i}} / 1000\right) S_{\mathrm{i}} / \\
{\left[\mathrm{F} 1(T)-\left(\rho_{\mathrm{i}} / 1000\right) S_{\mathrm{i}} \mathrm{F} 2(T)\right]} \\
S_{\mathrm{b}}(\%)=(1-54.11 / T)^{-1} \times 1000
\end{gathered}
$$

\section{Salinity, dissolved organic carbon/nitrogen and inorganic nutrients}

To obtain the salinity value corresponding to inorganic nutrients, the salinity of melted ice, brine and water samples was measured at laboratory temperature using a SEMAT Cond 315i/SET salinometer with a WTW Tetracon 325 probe. Samples were filtered through Whatman GF/F syringe filters (pore size $0.45 \mu \mathrm{m})$, stored on ice and frozen $\left(-18^{\circ} \mathrm{C}\right)$ on return to the laboratory until further analysis. The concentrations of the major dissolved inorganic nutrients, nitrate $\left(\mathrm{NO}_{3}{ }^{-}\right)$, nitrite $\left(\mathrm{NO}_{2}{ }^{-}\right)$, SRP (soluble reactive phosphorus, ) and silicic acid $\left(\mathrm{Si}(\mathrm{OH})_{4}\right)$ were determined by standard colorimetric methods (Grasshoff et al. 1983) as adapted for flow injection analysis (FIA) on a LACHAT Instruments Quick-Chem 8000 autoanalyzer (Hales et al. 2004). The concentration of dissolved ammonium $\left(\mathrm{NH}_{4}{ }^{+}\right)$was determined with the fluorimetric method of Holmes et al. (1999) using a HITACHI F2000 fluorescence spectrophotometer. Dissolved organic nitrogen (DON) concentrations were determined by subtraction of the concentration of dissolve inorganic nitrogen $\left(\mathrm{DIN}=\left[\mathrm{NO}_{2}{ }^{-}\right]+\left[\mathrm{NO}_{3}{ }^{-}\right]\right.$ $\left.+\left[\mathrm{NH}_{4}^{+}\right]\right)$from that of the total dissolved nitrogen (TDN) determined by FIA on the LACHAT autoanalyzer using on-line peroxodisulfate oxidation coupled with UV radiation at pH 9.0 and $100^{\circ} \mathrm{C}$ (Kroon 1993). The concentrations of dissolved organic carbon (DOC) were determined by high temperature combustion of acidified samples on an MQ 1001 TOC Analyzer (Qian \& Mopper 1996).

\section{Bacterial abundance and cell population characteristics}

Bacterial abundance and cell population characteristics were determined by flow cytometry following the methods outlined by Gasol et al. (1999) and Gasol \& del Giorgio (2000). Samples for determination of bacteria abundances were fixed with $0.2 \mu \mathrm{m}$ filtered electron microscopy-grade glutaraldehyde (final concentration of $0.5 \%$ ) and stored at $4^{\circ} \mathrm{C}$. Cells were stained with SYBR Green I (Molecular Probes) and samples were analyzed with an LSR II flow cytometer (BD Biosciences) using a $488 \mathrm{~nm}$ laser. A known 
amount of CountBright absolute counting beads (Molecular Probes) were added to each sample to calculate the accurate measured volume of each sample. Bacterial data were typically acquired until 50000 events were recorded and HNA and LNA cell populations identified from bivariate plots of green fluorescence (FITC) vs. right-angle light scatter (SSC). Gating analysis was performed using FACS Diva software (BD Biosciences). Cell abundance was calculated from processed sample volumes and number of events recorded. In addition, the median SSC parameter was defined for each cell population.

\section{Microscopic detection of polyhydroxyalkanoate-containing bacteria}

Potential polyhydroxyalkanoate (PHA) production in bacteria was identified using a modification of the widely used Nile Blue A staining method of Ostle \& Holt (1982) as follows: $5 \mathrm{ml}$ of each sample (same samples as for flow cytometry) were filtered onto a black $0.2 \mu \mathrm{m}$ polycarbonate filter (Osmonics) and stained for 15 min with $0.2 \mu \mathrm{m}$-filtered $1 \%(\mathrm{w} / \mathrm{v})$ aqueous solution of Nile Blue A sulfate (Sigma Aldrich). After staining, filters were rinsed 3 times with deionized water to remove excess stain. Filters were examined using a Leitz Aristoplan epifluorescence microscope with blue excitation (I3 filter) and a PL Fluotar $100 \times 12.5 / 20$ oil-immersion objective. Cells with orange-fluorescing bodies within them were imaged using a Photometrics CH250/A charged-couple device camera connected to a Leitz Aristoplan epifluorescence microscope and PMIS image-acquisition software. In addition to PHA, Nile Blue A can also selectively stain neutral lipid or wax ester inclusions inside bacterial cells. However, the production of these compounds has only been reported in a limited number of bacterial phyla that do not generally occur in sea ice (Ishige et al. 2003, Wältermann \& Steinbüchel 2005, Deming 2010). In contrast, the ability to produce PHA is widespread among prokaryotes.

\section{TdR and Leu incorporation, bacterial production}

For the measurement of bacterial production, samples containing a known amount of ice crush and seawater (Kaartokallio 2004) were prepared as follows: Each intact 5 to $10 \mathrm{~cm}$ ice core section was crushed using a spike and electrical ice cube crusher. Approximately $10 \mathrm{ml}$ of crushed ice was placed in a scintillation vial and weighed (with an accuracy of $\pm 0.1 \mathrm{~g}$ ). To maintain salinity and ensure even distribution of labeled substrate, 2 to $4 \mathrm{ml}$ sterile-filtered (through $0.2 \mu \mathrm{m}$ Sartorius minisart syringe filters) seawater was added to the scintillation vials. All ice processing work was done in a cool laboratory deck at near-zero temperatures.

Bacterial production was measured using ${ }^{14} \mathrm{C}$-Leu (Kirchman et al. 1985) and ${ }^{3} \mathrm{H}-\mathrm{TdR}$ (Fuhrman \& Azam 1980, 1982) incorporation methods and dual labeling. Two replicate samples and a formaldehyde-killed absorption blank were amended with L-[U- $\left.{ }^{14} \mathrm{C}\right] \mathrm{Leu}$ (PerkinElmer, specific activity $324 \mathrm{mCi} \mathrm{mmol}^{-1}$ ) diluted with carrier Leu at a proportion of 1:5 and [methyl- ${ }^{3} \mathrm{H}$ ] TdR (PerkinElmer, specific activity $20 \mathrm{Ci}$ $\mathrm{mmol}^{-1}$ ). Working concentrations of $20 \mathrm{nmol} \mathrm{l}^{-1}$ for TdR (all sample types) and $1000 \mathrm{nmol} \mathrm{l}^{-1}$ (ice and brine samples) and $500 \mathrm{nmol} \mathrm{l}^{-1}$ (water samples) for Leu were used. We used high concentrations of Leu exceeding typical concentrations used for seawater by 2 orders of magnitude, whereas the TdR concentrations used were of same order of magnitude as typically used for marine waters. The choice of the concentrations had to be made in advance due to the logistical constraints of working at a remote field station and the lack of opportunity to re-evaluate the working concentrations during the investigation. The concentrations were based on previous experience with Baltic Sea ice (Kaartokallio 2004, Kaartokallio et al. 2006).

Samples were incubated in the dark in a seawaterice crush water bath (at $-0.5 \pm 0.3^{\circ} \mathrm{C}$ ) for 17 to $18 \mathrm{~h}$, and incubations were stopped by adding formaldehyde. Samples were processed using a standard cold trichloroacetic acid (TCA) extraction (with 5\% TCA) and filtration procedure (using Advantec MFS $0.2 \mu \mathrm{m}$ MCE filters). A Wallac Win-Spectral 1414 counter and InstaGel (Perkin-Elmer) cocktail were used for scintillation counting. Bacterial production was calculated using a cell conversion factor of $2.09 \times 10^{18}$ cells $\mathrm{mol}^{-1}$, cell volume of $0.473 \mu \mathrm{m}^{3}$ and carbon conversion factor of $0.12 \mathrm{pg} \mathrm{C} \mathrm{m}^{3}$ for TdR (Smith \& Clement 1990). Leu-based bacterial production was calculated using a factor of $3.0 \mathrm{~kg} \mathrm{C} \mathrm{mol}^{-1}$ (Bjørnsen \& Kuparinen 1991).

A saturation kinetics experiment was conducted on Day 2 for both TdR and Leu and the 3 major sample types. Ice samples were combined from 4 separate bottom ice sections taken alongside the normal sampling on Day 2, brine was sampled from the upper brine horizon on Day 1 (sackhole depth approximately $40 \mathrm{~cm}$ ) and water was taken from $9 \mathrm{~m}$ depth on Day 2. The concentrations used were 5, 10, 14, 30 
and $50 \mathrm{nmol}^{-1}$ TdR for all sample types, 200, 700, 1500, 2000 and $2500 \mathrm{nmol} \mathrm{l}^{-1}$ Leu for ice and brine samples, and 100, 350, 750, 1000 and $1250 \mathrm{nmol} \mathrm{l}^{-1}$ Leu for water samples.

Experimental data were fitted with the single kinetic Michaelis-Menten equation $V=V_{\max } \times S /\left[\left(K_{\mathrm{t}}\right.\right.$ $\left.+S_{\mathrm{n}}\right)+S$ ], (where $V=$ incorporation rate, $V_{\max }=$ maximum incorporation rate, $K_{\mathrm{t}}+S_{\mathrm{n}}=$ apparent halfsaturation constant, i.e. half-saturation constant + natural leucine/thymidine concentration), $S=$ added leucine/thymidine concentration), using SigmaPlot 10 software (SPSS). Saturating concentrations were defined as substrate concentrations where $90 \%$ of $V_{\max }$ was reached and calculated as $V_{\max 90}=9 \times K_{\mathrm{t}}+$ $S_{\mathrm{n}}$ (Ayo et al. 2001). Isotope dilution was assessed as a ratio of $V_{\max }$ and $V_{\text {measured }}$ at the saturating concentration (van Looij \& Riemann 1993, Buesing \& Gessner 2003). Incorporation kinetics experiments were conducted with a $16 \mathrm{~h}$ incubation at $4 \mathrm{~h}$ intervals for all 3 sample types on Day 3 using water from immediately under the ice, and brine and bottom ice samples from Day 3 sampling.

\section{Statistical analyses}

Statistical analyses were done using base, Psych, Vegan and MASS packages of R software (R Development Core Team 2011). Differences between more than 2 sample types were verified using the KruskalWallis rank (KW) sum test with the pairwise Wilcoxon rank sum post hoc test (Wp-h) and Bonferroni adjustment or, when comparing 2 sample types using Wilcoxon rank sum tests (W). For non-metric multidimensional scaling (NMDS), Spearman's rank-order correlations between bacterial and environmental parameters were calculated. NMDS was performed on a Bray-Curtis dissimilarity matrix of bacterial parameters with metaMDS wrapper routine included in the Vegan package (Oksanen et al. 2012). Environmental parameters were fitted on the NMDS plot using the function, ef, included in the Vegan package.

\section{RESULTS}

For analyses, ice core sections were divided into 3 classes: 'upper ice', the 2 uppermost ice sections (upper- most $24 \mathrm{~cm}$ of ice), 'bottom ice', the lowermost $4 \mathrm{~cm}$ ice section at ice-water interface, and 'middle ice', the ice sections between the other 2 classes. Brine samples from both brine sampling horizons as well as water samples from 2 sampling depths were pooled to form sample classes 'brine' and 'water', respectively.

\section{Physical and chemical parameters}

Ice temperature, salinity and brine volumes are presented in Fig. 1 and Table 1. Differences in the 3 parameters between sampling days were not statistically significant as verified by the KW tests. The ice temperature varied from -3.8 to $-0.8^{\circ} \mathrm{C}$, displaying typical near-linear profiles increasing with ice depth (Fig. 1). Ice bulk salinity was significantly higher in bottom ice compared to upper and middle ice (KW $\chi^{2}$ $=17.64, \mathrm{p}<0.001, \mathrm{Wp}-\mathrm{h}$ both $\mathrm{p}<0.008)$. Calculated brine volumes were generally below $10 \%$ except in the bottom ice. The underlying water had median salinity of 33.1 with small temporal variability.

Inorganic and organic nutrient concentrations are presented in Table 1. Both DOC and DON concentrations were higher in bottom ice compared to middle and upper ice (KW, DOC: $\chi^{2}=8.39, \mathrm{p}=0.015$, DON: $\left.\chi^{2}=11.89, \mathrm{p}<0.003\right) . \mathrm{NO}_{3}{ }^{-}$concentrations were significantly higher in bottom ice compared to middle ice $\left(\mathrm{NO}_{3}^{-}: \chi^{2}=10.61, \mathrm{p}<0.005\right)$ but not upper ice (Wp-h for DOC, DON and $\mathrm{NO}_{3}{ }^{-}$all $\mathrm{p}<0.05$ ). Surprisingly, apart from silicate, brine and ice concentrations of dissolved inorganic nutrients were similar, despite the salinity contrast between bulk ice and

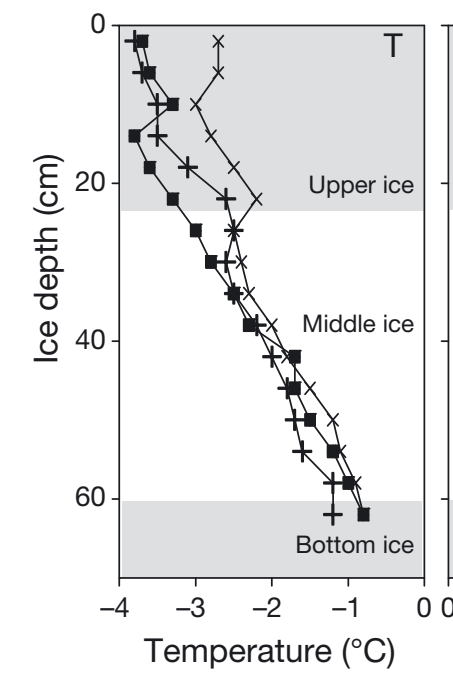

Fig. 1. Temperature $(T)$, salinity $(S)$ and brine volume $\left(V_{\mathrm{b}}\right)$ profiles in ice on Days 2 , 4 and 6 . The 3 ice layers used are indicated by different shading 
Table 1. Salinity, inorganic nutrients, dissolved organic carbon (DOC) and nitrogen (DON) in melted sea ice, brine and water. $\mathrm{SRP}=$ soluble reactive phosphorus, $\mathrm{Si}=$ silicic acid $\left(\mathrm{Si}(\mathrm{OH})_{4}\right)$. Mean, range (in parentheses) and standard deviation for each sample class are given

\begin{tabular}{|c|c|c|c|c|c|}
\hline & Upper ice & Middle ice & Bottom ice & Brine & Water \\
\hline Salinity & $\begin{array}{c}3.42(2.90-4.00) \\
0.46, \mathrm{n}=10\end{array}$ & $\begin{array}{c}2.55(1.8-3.5) \\
0.62, \mathrm{n}=15\end{array}$ & $\begin{array}{c}5.18(4.6-6.1) \\
0.66, n=5\end{array}$ & $\begin{array}{c}48.3(42.9-55.6) \\
4.61, \mathrm{n}=8\end{array}$ & $\begin{array}{c}33.1(32.7-33.4) \\
0.36, \mathrm{n}=3\end{array}$ \\
\hline $\mathrm{SRP}\left(\mu \mathrm{mol} \mathrm{l} \mathrm{l}^{-1}\right)$ & $\begin{array}{c}\mathbf{0 . 1 3}(0.06-0.26) \\
0.07, \mathrm{n}=10\end{array}$ & $\begin{array}{c}\mathbf{0 . 1 9}(0.04-0.72) \\
0.2, \mathrm{n}=15\end{array}$ & $\begin{array}{c}\mathbf{0 . 6 3}(0.1-2.56) \\
1.08, \mathrm{n}=5\end{array}$ & $\begin{array}{c}\mathbf{0 . 2}(0.16-0.32) \\
0.05, \mathrm{n}=8\end{array}$ & $\begin{array}{c}1.42(0.78-2.56) \\
0.99, \mathrm{n}=3\end{array}$ \\
\hline $\mathrm{Si}\left(\mu \mathrm{mol} \mathrm{l} \mathrm{l}^{-1}\right)$ & $\begin{array}{c}5.38(2.80-7.74) \\
2.16, n=10\end{array}$ & $\begin{array}{c}4.72(2.29-7.96) \\
2.0, \mathrm{n}=15\end{array}$ & $\begin{array}{c}\mathbf{5 . 9 7}(5.2-6.7) \\
0.65, \mathrm{n}=5\end{array}$ & $\begin{array}{c}83.1(75.6-97.1) \\
7.43, \mathrm{n}=8\end{array}$ & $\begin{array}{c}\mathbf{6 . 8 7}(6.68-7.01) \\
0.15, \mathrm{n}=3\end{array}$ \\
\hline $\mathrm{NO}_{3}^{-}\left(\mu \mathrm{mol} \mathrm{l} l^{-1}\right)$ & $\begin{array}{c}\mathbf{0 . 7 7}(0.31-1.66) \\
0.40, \mathrm{n}=10\end{array}$ & $\begin{array}{c}\mathbf{0 . 4 0}(0.06-0.95) \\
0.2, \mathrm{n}=15\end{array}$ & $\begin{array}{c}\mathbf{0 . 9 3}(0.68-1.47) \\
0.31, \mathrm{n}=5\end{array}$ & $\begin{array}{c}\mathbf{0 . 8 2}(0.41-2.2) \\
0.57, \mathrm{n}=8\end{array}$ & $\begin{array}{c}8.67(8.60-8.80) \\
0.12, \mathrm{n}=3\end{array}$ \\
\hline $\mathrm{NO}_{2}^{-}\left(\mu \mathrm{mol} \mathrm{l} l^{-1}\right)$ & $\begin{array}{c}\mathbf{0 . 0 5}(0.0-0.10) \\
0.03, \mathrm{n}=10\end{array}$ & $\begin{array}{c}\mathbf{0 . 0 4}(0.0-0.11) \\
0.03, \mathrm{n}=15\end{array}$ & $\begin{array}{c}\mathbf{0 . 0 4}(0.0-0.12) \\
0.05, \mathrm{n}=5\end{array}$ & $\begin{array}{c}\mathbf{0 . 0 3}(0.0-0.09) \\
0.04, \mathrm{n}=8\end{array}$ & $\begin{array}{c}\mathbf{0 . 0 7}(0.03-0.11) \\
0.04, \mathrm{n}=3\end{array}$ \\
\hline $\mathrm{NH}_{4}{ }^{+}\left(\mu \mathrm{mol} \mathrm{l} l^{-1}\right)$ & $\begin{array}{c}\mathbf{0 . 4 7}(0.01-0.86) \\
0.27, \mathrm{n}=10\end{array}$ & $\begin{array}{c}\mathbf{0 . 6 4}(0.24-2.75) \\
0.62, \mathrm{n}=15\end{array}$ & $\begin{array}{c}\mathbf{0 . 7 1}(0.35-1.34) \\
0.38, \mathrm{n}=5\end{array}$ & $\begin{array}{c}\mathbf{0 . 7 6}(0.56-0.94) \\
0.11, \mathrm{n}=8\end{array}$ & $\begin{array}{c}\mathbf{0 . 3 1}(0.28-0.35) \\
0.04, \mathrm{n}=3\end{array}$ \\
\hline $\mathrm{DON}\left(\mu \mathrm{mol} \mathrm{l^{-1 }}\right)$ & $\begin{array}{c}2.51(1.49-3.06) \\
0.53, \mathrm{n}=8\end{array}$ & $\begin{array}{c}3.35(1.64-7.4) \\
1.48, \mathrm{n}=13\end{array}$ & $\begin{array}{c}6.09(5.14-7.03) \\
0.7, n=5\end{array}$ & $\begin{array}{c}24.3(21.1-28.0) \\
2.34, \mathrm{n}=8\end{array}$ & $\begin{array}{c}1.6(1.50-1.70) \\
0.1, \mathrm{n}=3\end{array}$ \\
\hline $\mathrm{DOC}\left(\mu \mathrm{mol} \mathrm{l} \mathrm{l}^{-1}\right)$ & $\begin{array}{c}\mathbf{5 6 . 0}(34.6-80.9) \\
12.6, \mathrm{n}=10\end{array}$ & $\begin{array}{c}\mathbf{5 2 . 1}(34.2-78.5) \\
14.9, \mathrm{n}=15\end{array}$ & $\begin{array}{c}\mathbf{8 0 . 2}(64.0-106) \\
17.0, \mathrm{n}=5\end{array}$ & $\begin{array}{c}\mathbf{6 2 0}(581-651) \\
25.6, \mathrm{n}=8\end{array}$ & $\begin{array}{c}62.9(55.3-68.5) \\
56.8, \mathrm{n}=3\end{array}$ \\
\hline DOC:DON & $\begin{array}{c}22.0(15.9-28.9) \\
4.8, \mathrm{n}=8\end{array}$ & $\begin{array}{c}16.9(5.89-26.7) \\
6.53, \mathrm{n}=13\end{array}$ & $\begin{array}{c}13.1(11.0-15.2) \\
1.56, \mathrm{n}=5\end{array}$ & $\begin{array}{c}25.7(23.2-30.9) \\
2.64, \mathrm{n}=8\end{array}$ & $\begin{array}{c}39.3(37.0-42.0) \\
2.51, \mathrm{n}=3\end{array}$ \\
\hline
\end{tabular}

brine. Small scale spatial variability, measured from 5 separate upper ice sections, was lowest for salinity and $\mathrm{Si}(\mathrm{OH})_{4}$ with a coefficient of variation $(\mathrm{CV})$ of $9 \%$. The CV was $16 \%$ for DOC and DOC:DON, 25 to $32 \%$ for $\mathrm{DON}, \mathrm{NO}_{3}{ }^{-}, \mathrm{SRP}$ and $\mathrm{NH}_{4}{ }^{+}$, and $54 \%$ for $\mathrm{NO}_{2}{ }^{-}$. Temporal variability in the top $12 \mathrm{~cm}$ section over the study period was lowest for salinity (CV $2 \%$ ), $63 \%$ for $\mathrm{NH}_{4}{ }^{+}$, and 21 to $41 \%$ for all other parameters mentioned above. Temporal variability significantly exceeded small-scale spatial variability in the ice top section as seen in higher average CVs $(\mathrm{W}=85, \mathrm{p}<0.0005)$.

\section{Bacterial abundance, cell population characteristics}

Bacterial abundance was rather low in all sample types (Fig. 2), but comparable to the abundances described by Middelboe et al. (2012) in the water column of an adjacent fjord system. Bacterial abundance in ice was highest in the bottom ice layer $\left(\mathrm{KW} \chi^{2}=\right.$ 21.18, $\mathrm{p}<0.001$, Wp-h $\mathrm{p}<0.004)$. Abundances in water and brines were similar and not significantly different from bottom ice. Bacterial abundance in brine was signifi- cantly higher than in the corresponding ice sections (W $=120, \mathrm{p}<0.001$ ), but approximately 2 times lower than expected based on the calculated brine volume fraction.

HNA and LNA cells contributed almost equally to the total bacterial abundance in ice. HNA:LNA ratios (Table 2) ranged from 0.66 in upper ice to 1.09 in bottom ice and were significantly different between sample types (KW $\left.\chi^{2}=9.85, \mathrm{p}<0.008\right)$. The HNA: LNA ratio in water was only 0.33 , and significantly lower than in bottom ice $(\mathrm{W}=34, \mathrm{p}<0.05)$. The HNA

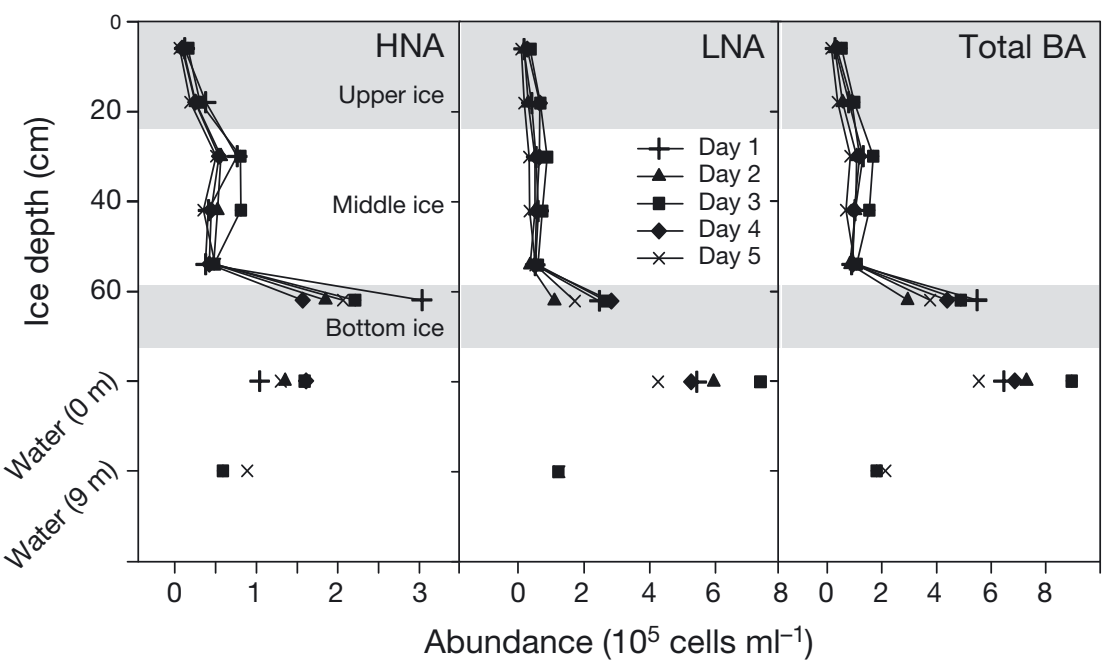

Fig. 2. Abundance of high-nucleic-acid (HNA), low-nucleic-acid (LNA) and total (HNA + LNA) bacteria (BA) in ice layers and underlying water 
Table 2. Leucine (Leu) and thymidine (TdR) incorporation, bacterial production (BP) and bacterial abundance in melted sea ice, brine and underlying water. HNA = high nucleic acid, LNA = low nucleic acid. Mean, range (in parentheses) and standard deviation for each sample class are given

\begin{tabular}{|c|c|c|c|c|c|}
\hline & Upper ice & Middle ice & Bottom ice & Brine & Water \\
\hline Leu $\left(p m o l l^{-1} h^{-1}\right)$ & $\begin{array}{c}23.4(0.9-48.8) \\
15.1, \mathrm{n}=8\end{array}$ & $\begin{array}{c}24.4(9.22-52.8) \\
13.2, \mathrm{n}=12\end{array}$ & $\begin{array}{c}737(546-1030) \\
219, \mathrm{n}=4\end{array}$ & $\begin{array}{c}179(141-229) \\
27.64, \mathrm{n}=8\end{array}$ & $\begin{array}{c}181.6(148-210) \\
25.1, \mathrm{n}=5\end{array}$ \\
\hline $\operatorname{TdR}\left(p m o l l^{-1} h^{-1}\right)$ & $\begin{array}{c}\mathbf{0 . 1 7}(0.02-0.32) \\
0.10, \mathrm{n}=10\end{array}$ & $\begin{array}{c}\mathbf{0 . 4 1}(0.17-0.65) \\
0.16, \mathrm{n}=15\end{array}$ & $\begin{array}{c}2.55(1.45-3.8) \\
1.08, n=5\end{array}$ & $\begin{array}{c}3.45(1.84-5.56) \\
1.21, \mathrm{n}=8\end{array}$ & $\begin{array}{c}2.65(1.83-3.88) \\
0.83, \mathrm{n}=7\end{array}$ \\
\hline Leu:TdR & $\begin{array}{c}145(41.7-202) \\
46.7, \mathrm{n}=8\end{array}$ & $\begin{array}{c}60.1(42.3-85.8) \\
14.4, \mathrm{n}=12\end{array}$ & $\begin{array}{c}269(205-313) \\
46.0, \mathrm{n}=4\end{array}$ & $\begin{array}{c}57.6(35.7-98.8) \\
21.4, \mathrm{n}=8\end{array}$ & $\begin{array}{c}69.1(52.3-80.9) \\
12.2, \mathrm{n}=5\end{array}$ \\
\hline BP Leu $\left(\mu g C \mathrm{l}^{-1} \mathrm{~h}^{-1}\right)$ & $\begin{array}{c}\mathbf{0 . 0 7}(0-0.15) \\
0.05, \mathrm{n}=8\end{array}$ & $\begin{array}{c}\mathbf{0 . 0 7}(0.03-0.16) \\
0.04, \mathrm{n}=12\end{array}$ & $\begin{array}{c}2.21(1.64-3.09) \\
0.66, n=4\end{array}$ & $\begin{array}{c}\mathbf{0 . 5 4}(0.42-0.69) \\
0.08, \mathrm{n}=8\end{array}$ & $\begin{array}{c}\mathbf{0 . 4 5}(0.03-0.63) \\
0.23, \mathrm{n}=5\end{array}$ \\
\hline BP TdR $\left(\mu g C l^{-1} h^{-1}\right)$ & $\begin{array}{c}\mathbf{0 . 0 2}(0-0.04) \\
0.01, \mathrm{n}=10\end{array}$ & $\begin{array}{c}\mathbf{0 . 0 5}(0.02-0.08) \\
0.02, \mathrm{n}=15\end{array}$ & $\begin{array}{c}\mathbf{0 . 3 0}(0.17-0.45) \\
0.13, \mathrm{n}=5\end{array}$ & $\begin{array}{c}\mathbf{0 . 4 1}(0.22-0.66) \\
0.14, \mathrm{n}=8\end{array}$ & $\begin{array}{c}0.32(0.22-0.46) \\
0.10, \mathrm{n}=7\end{array}$ \\
\hline $\begin{array}{l}\text { HNA bacteria } \\
\left(\times 10^{4} \text { cells } \mathrm{ml}^{-1}\right)\end{array}$ & $\begin{array}{c}1.91(0.59-3.79) \\
1.05, \mathrm{n}=10\end{array}$ & $\begin{array}{c}5.32(3.43-8.08) \\
1.48, \mathrm{n}=15\end{array}$ & $\begin{array}{c}21.4(15.7-30.3) \\
5.54, \mathrm{n}=5\end{array}$ & $\begin{array}{c}25.4(17.5-34.4) \\
6.52, \mathrm{n}=8\end{array}$ & $\begin{array}{c}13.0(8.88-16.1) \\
2.89, \mathrm{n}=7\end{array}$ \\
\hline $\begin{array}{l}\text { LNA bacteria } \\
\left(\times 10^{4} \text { cells } \mathrm{ml}^{-1}\right)\end{array}$ & $\begin{array}{c}3.36(1.0-6.81) \\
2.00, \mathrm{n}=10\end{array}$ & $\begin{array}{c}\mathbf{5 . 4 9}(3.43-8.83) \\
1.43, \mathrm{n}=15\end{array}$ & $\begin{array}{c}21.6(11.0-28.3) \\
7.31, \mathrm{n}=5\end{array}$ & $\begin{array}{c}21.0(11.0-36.1) \\
8.62, \mathrm{n}=8\end{array}$ & $\begin{array}{c}49.2(12.5-73.7) \\
20.1, \mathrm{n}=7\end{array}$ \\
\hline HNA:LNA & $\begin{array}{c}\mathbf{0 . 6 1}(0.32-0.97) \\
0.23, \mathrm{n}=10\end{array}$ & $\begin{array}{c}\mathbf{0 . 9 9}(0.67-1.48) \\
0.24, \mathrm{n}=15\end{array}$ & $\begin{array}{c}1.09(0.55-1.67) \\
0.43, \mathrm{n}=5\end{array}$ & $\begin{array}{c}1.30(0.89-1.77) \\
0.32, \mathrm{n}=8\end{array}$ & $\begin{array}{c}0.33(0.19-0.71) \\
0.19, \mathrm{n}=7\end{array}$ \\
\hline $\begin{array}{l}\text { Total bacteria } \\
\left(\times 10^{4} \text { cells } \mathrm{ml}^{-1}\right)\end{array}$ & $\begin{array}{c}5.28(1.58-9.92) \\
2.85, \mathrm{n}=10\end{array}$ & $\begin{array}{c}10.9(6.98-16.9) \\
2.64, \mathrm{n}=15\end{array}$ & $\begin{array}{c}43.0(29.4-55.0) \\
9.9, \mathrm{n}=5\end{array}$ & $\begin{array}{c}46.4(28.6-68.4) \\
14.3, \mathrm{n}=8\end{array}$ & $\begin{array}{c}62.2(21.3-89.6) \\
23.0, n=7\end{array}$ \\
\hline
\end{tabular}

Table 3. Right-angle light scatter (SSC) parameter for the high (HNA) and low nucleic acid (LNA) populations and cell-specific thymidine (TdR cell ${ }^{-1}$ ) and leucine (Leu cell ${ }^{-1}$ ) incorporation in sea ice, brine and underlying water. Mean, range (in parentheses) and standard deviation for each sample class are given

\begin{tabular}{|lcccccc|}
\hline & Upper ice & Middle ice & Bottom ice & Brine & Water 0 m & Water 9 m \\
\hline HNA SSC & $\mathbf{6 8 8}(421-913)$ & $\mathbf{7 6 3}(610-914)$ & $\mathbf{9 2 6}(747-1135)$ & $\mathbf{9 8 9}(846-1111)$ & $\mathbf{7 4 8}(678-838)$ & $\mathbf{5 1 2}(499-524)$ \\
& $131, \mathrm{n}=10$ & $97.8, \mathrm{n}=15$ & $140, \mathrm{n}=5$ & $82, \mathrm{n}=8$ & $66.5, \mathrm{n}=4$ & $18, \mathrm{n}=2$ \\
LNA SSC & $\mathbf{4 4 4}(327-582)$ & $\mathbf{4 4 6}(386-523)$ & $\mathbf{3 7 5}(283-568)$ & $\mathbf{5 2 8}(399-582)$ & $\mathbf{3 2 8}(299-349)$ & $\mathbf{3 6 4}(361-367)$ \\
& $84, \mathrm{n}=10$ & $53.4, \mathrm{n}=15$ & $112, \mathrm{n}=5$ & $62, \mathrm{n}=8$ & $18.0, \mathrm{n}=5$ & $4, \mathrm{n}=2$ \\
Leu cell $^{-\mathbf{1}}\left(\times 10^{-7}\right.$ & $\mathbf{7 . 1 3}(0.30-30.8)$ & $\mathbf{2 . 3 8}(0.70-5.21)$ & $\mathbf{1 6 . 5}(10.8-23.4)$ & $\mathbf{4 . 1 4}(2.06-5.77)$ & $\mathbf{2 . 6 9}(2.27-3.13)$ & $\mathbf{8 . 0 1}$ \\
pmol cell $\left.^{-1} \mathrm{~h}^{-1}\right)$ & $9.97, \mathrm{n}=8$ & $1.43, \mathrm{n}=12$ & $6.48, \mathrm{n}=4$ & $1.10, \mathrm{n}=8$ & $0.46, \mathrm{n}=5$ & $\mathrm{n}=1$ \\
TdR cell $^{-1}\left(\times 10^{-9}\right.$ & $\mathbf{5 . 1 9}(0.50-18.9)$ & $\mathbf{4 . 0 2}(1.29-7.02)$ & $\mathbf{6 . 1 5}(3.45-10.1)$ & $\mathbf{7 . 8 4}(4.06-12.8)$ & $\mathbf{3 . 8 5}(2.83-5.07)$ & $\mathbf{1 0 . 7}$ \\
pmol cell $\left.^{-1} \mathrm{~h}^{-1}\right)$ & $5.80, \mathrm{n}=10$ & $1.95, \mathrm{n}=15$ & $2.89, \mathrm{n}=5$ & $3.11, \mathrm{n}=8$ & $0.95, \mathrm{n}=5$ & $\mathrm{n}=1$ \\
\hline
\end{tabular}

bacteria cell size proxy in brines (mean SSC parameter, Table 3) was significantly higher than in under-ice water, and the upper and middle ice layers $\left(\mathrm{KW} \chi^{2}=23.74, \mathrm{p}<0.001\right.$, Wp-h all $\left.\mathrm{p}<0.015\right)$ but there was no significant difference for bottom ice. In ice, HNA SSC was significantly higher in bottom ice than upper ice (KW $\chi^{2}=8.81, \mathrm{p}<0.013$, Wp-h p < 0.04). Under-ice water had lower mean HNA SSC than bottom ice or brine, although only the differences between brine and water were statistically significant ( $\mathrm{W}=36, \mathrm{p}<0.008$ ). The variability of LNA SSC was generally low with significantly higher LNA SSC in brine and middle ice layers as compared to under-ice water $\left(\mathrm{KW} \chi^{2}=21.43, \mathrm{p}<0.001\right.$, Wp-h all $\mathrm{p}<0.015)$.

\section{TdR and Leu incorporation, bacterial production and respiration}

Bacterial production data are presented in Table 2 and Fig. 3. For both Leu and TdR, temporal variability was moderate and pronounced incorporation in the bottom ice occurred throughout the study period. Leu incorporation in the bottom ice significantly exceeded the under-ice water values ( $\mathrm{W}=32, \mathrm{p}<$ 0.005), whereas bottom ice and under-ice TdR values were not significantly different. Temporal variability of TdR in under-ice water was higher than for Leu, and both under-ice water and water from $9 \mathrm{~m}$ depth had comparable values. In the brines, both Leu and TdR exceeded upper and middle ice values by a fac- 


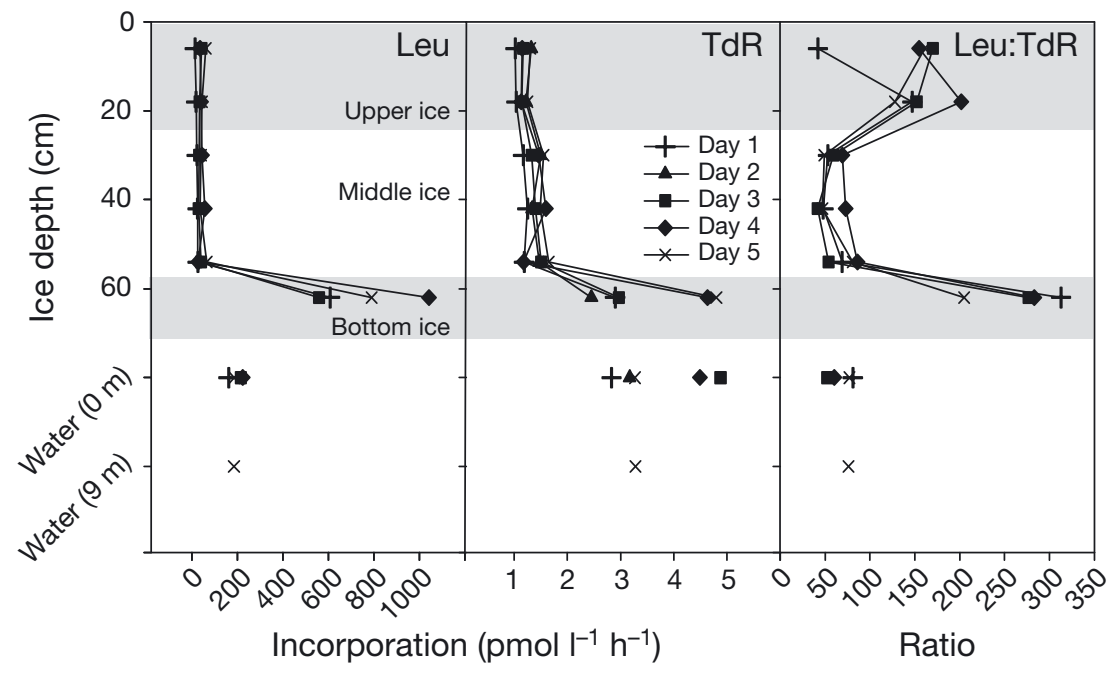

Fig. 3. Leucine (Leu) and thymidine (TdR) incorporation and their ratios in ice and water

\section{Leu:TdR ratios}

Leu:TdR ratios in the ice were consistently lowest in the middle ice layers and highest in the upper and bottom ice layers during the sampling period (Fig. 3). The ratio was higher $(\mathrm{W}=32, \mathrm{p}<0.005)$ in the bottom ice and variability was lower in bottom than in upper ice horizons (Fig. 3). In middle ice layers and brine and under-ice waters, the Leu:TdR ratios were not significantly different. The Leu:TdR ratios in under-ice water were at the higher end of the range reported for other marine systems (Chin-Leo \& Kirchman 1990, Kirchman 1992, Shiah \& Ducklow 1997). tor of 7 to 8 , which is in line with the estimated brine volume fraction in the middle layer (Fig. 1). Bacterial production estimates produced with the 2 tracers were not significantly different in middle ice, brine and water, whereas the mean Leu-based production estimates for the upper and bottom ice were significantly higher than the TdR-based estimates, being 3.5 times $(\mathrm{W}=65, \mathrm{p}<0.03)$ and 7.3 times $(\mathrm{W}=20, \mathrm{p}<$ $0.016)$ higher, respectively.

To assess whether bacterial productivity measurements gave realistic results they were related to independent oxygen flux measurements from the same site and study period, published by Long et al. (2012). Bacterial respiration was calculated for the bottom ice layer, using 3 different bacterial growth efficiencies and 2 Leu conversion factors to generate a range of values. The bacterial growth efficiency values used were (1) a calculated value of 0.384 according to Rivkin \& Legendre (2001), (2) a mean value of 0.386 for a control unit at $0^{\circ} \mathrm{C}$ presented by Kuparinen et al. (2011), and (3) the high Arctic sea ice-bottom average value of 0.24 from Nguyen \& Maranger (2011).

For respiration estimates, theoretical conversion factor extremes of 1.5 and $3.0 \mathrm{~kg} \mathrm{C} \mathrm{mol}^{-1}$ Leu were used (Simon \& Azam 1989), which have also been empirically validated for cold seawater environments (Bjørnsen \& Kuparinen 1991, Ducklow et al. 2000, Ducklow 2003). Bacterial carbon respiration was converted to oxygen consumption assuming a respiratory quotient of 1 . Ranges and median (in parentheses) values for bottom-ice bacterial respiration for the entire study period were 1.7 to 6.72 (3.37) $\mathrm{O}_{2} \mathrm{~m}^{-2} \mathrm{~d}^{-1}$ for Leu-, and 0.50 to $1.02(0.52) \mathrm{O}_{2} \mathrm{~m}^{-2} \mathrm{~d}^{-1}$ for TdRbased production estimates.

\section{Saturation and incorporation kinetics}

Apparent half-saturation constants $\left(K_{\mathrm{t}}+S_{\mathrm{n}}\right)$ were variable across sample types for both Leu and TdR tracers (Fig. 4). We did not take natural background concentrations into account in the calculations, and apparent $\left(K_{\mathrm{t}}+S_{\mathrm{n}}\right)$ values include the ambient Leu and TdR concentrations. The results indicated that, despite the high Leu working concentrations used, the ice samples were still under-saturated in respect to both tracers ( $V_{\max 90}$ :working concentration ratio was 1.6 for TdR and 2.07 for Leu). In brines, the $V_{\max 90}$ :working concentration ratio was 1.8 for TdR, whereas added tracer concentration exceeded the estimated saturation level in brines for Leu and in water for both tracers. Isotope dilution was estimated to be small and varied little across sample types and tracers (range 1.02 to 1.08 for TdR and 1.08 to 1.10 for Leu). $V_{\max }$ values reflecting the maximum incorporation potential in samples were equal in brine and water for both tracers, but 2 times higher for TdR, and an order of magnitude higher for Leu in bottom ice. In a separate incorporation linearity test, the incorporation rates were stable over the $16 \mathrm{~h}$ incubation used for both tracers and for all sample types (data not shown).

\section{Cell-specific incorporation}

Cell-specific incorporation for Leu and TdR was calculated using total bacterial abundance and incorporation (Table 3). Cell-specific TdR was less variable as a function of ice layer than cell-specific Leu. Cell- 

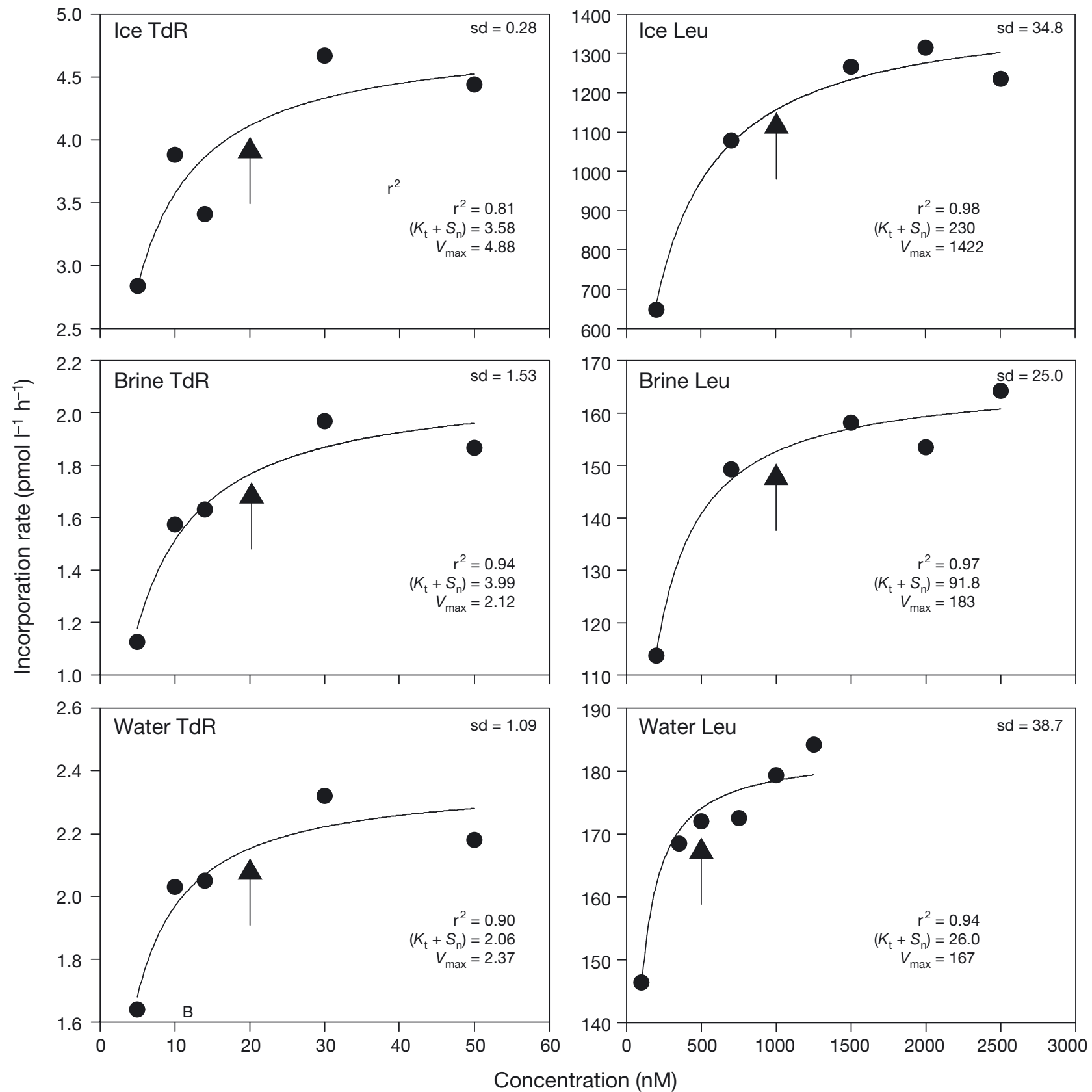

Fig. 4. Saturation experiment results with fitted non-linear Michaelis-Menten kinetics. $V_{\max }, K_{\mathrm{t}}+S_{\mathrm{n}}$ and adjusted $\mathrm{r}^{2}$ values are shown. The arrows indicate working concentrations used in the measurements. 'sd' denotes the overall standard deviation of all thymidine (TdR) or leucine (Leu) measurements for Days 1 to 3

specific TdR was not significantly different in ice layers $\left(\mathrm{KW} \chi^{2}=2.250, \mathrm{p}<0.325\right)$, whereas mean cell-specific Leu was almost 7 -fold and significantly higher in the bottom ice $\left(\chi^{2}=9.037, \mathrm{p}<0.011\right)$ compared to middle ice (Wp-h $\mathrm{p}<0.013)$, but not upper ice samples $(p<0.152)$. In brines, the cell-specific TdR and Leu were significantly higher than in the middle ice layers (Leu: $\mathrm{W}=79, \mathrm{p}<0.016$; TdR: $\mathrm{W}=102, \mathrm{p}<0.006$ ). In the under-ice water, the cell-specific incorporation was not significantly different from upper and middle ice layers for both tracers, but significantly lower than in bottom ice for Leu ( $\mathrm{W}=0, \mathrm{p}<0.007)$.

\section{NMDS}

Following NMDS analysis, different ice layers were separated into distinct clusters (Fig. 5), whereas 


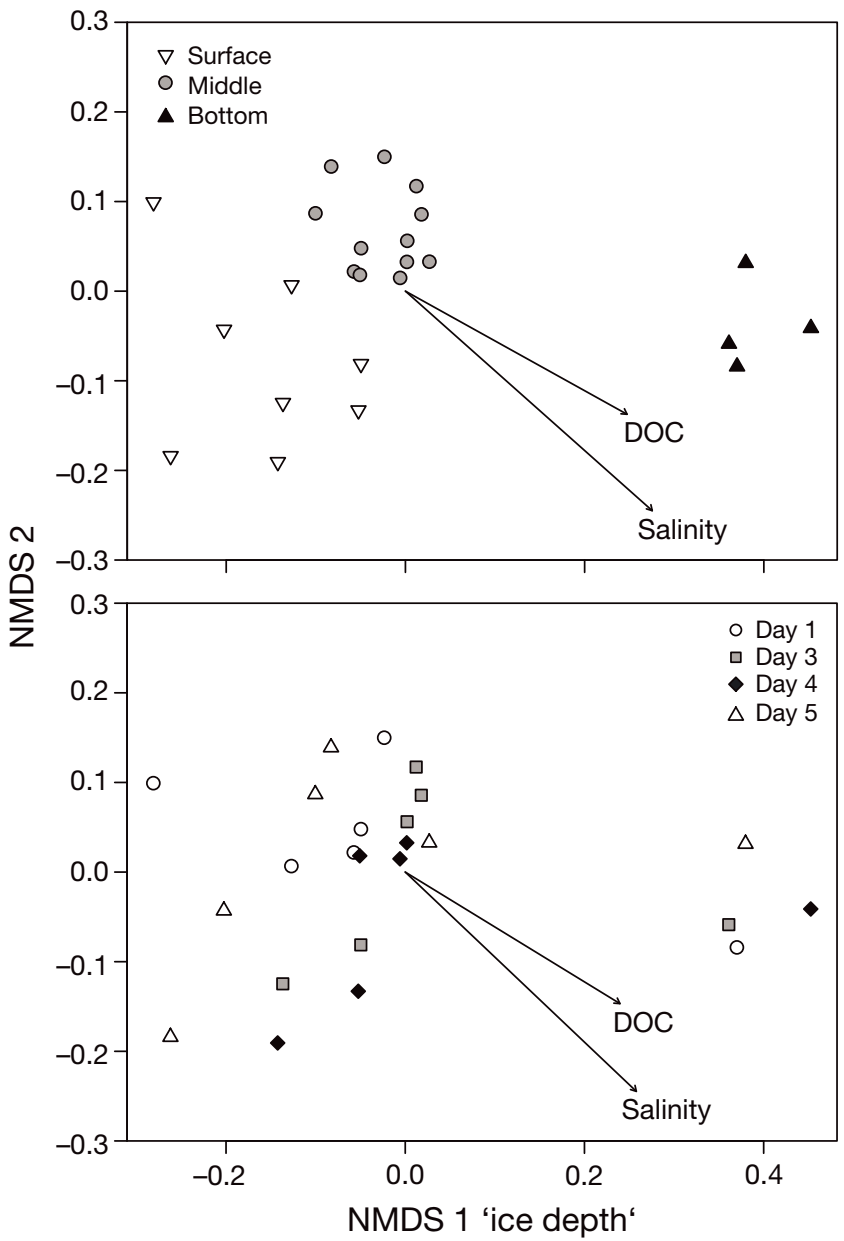

Fig. 5. Non-metric multi-dimensional scaling (NMDS) of bacterial parameters in ice (presented in Table 2) with physicochemical parameters (presented in Table 1) correlated with the distance matrix (correlations with $\mathrm{p}<0.05$ are displayed). Ice sections are plotted in the upper panel and sampling days in the lower panel

sampling days were not different from each other. Based on the NMDS results, the main NMDS axis 1 was identified as 'ice depth'. Parameters presented in Table 1 were correlated with the NMDS distance matrix and only the DOC:DON ratio and salinity were correlated on a 95\% significance level. Highest non-significant correlations were with DOC:DON (80\% confidence level) and DON, SRP and $\mathrm{NO}_{3}{ }^{-}$ (70\% confidence level).

\section{Cells containing putative PHA granules}

Cells containing putative PHA granules (i.e. brightly fluorescing intracellular inclusions observed following the Nile Blue A stain) were found in all ice layers and in the underlying water samples (Fig. 6).
They were most abundant in the bottom ice, although they were only a minor portion of all bacterial cells present. Unfortunately, the method employed did not allow their quantitative determination. Three main morphotypes of 'PHA-containing' cells were found: (1) long filaments with numerous PHA granules inside the cells; (2) shorter filaments or elongated rods with 3 to 4 granules inside the cell; and (3) cells with single and double granules. In doubles, one of the granules was typically brighter, the lessintense granule possibly being inside a daughter cell. All 3 general morphotypes were present in bottom, middle and upper ice, and brine. In the under-ice waters, only single or double granules were observed. Granule-containing bacteria were often associated with diatoms in bottom ice and detrital particles in other parts of the ice. In acridine orange-stained samples, bacterial cells and filaments with visible inclusions corresponding to the shape and size of PHA granules were recorded (not shown).

\section{DISCUSSION}

The sea ice sampling design covered both temporal and small-scale spatial variability. Limited assessment of small-scale spatial variability of salinity, dissolved nutrients, DOC and DON indicated that it was significantly lower than the temporal variability over the study period (c.f. Søgaard et al. 2013). The smallscale spatial variability investigation did not include bacterial parameters, but low spatial variability in salinity and nutrients is expected to be reflected in bacterial parameters as, based on NMDS, environmental variables seemed to drive changes in them (see below). Furthermore, snow cover, a major controlling factor for organism biomass variability in lower ice (Gosselin et al. 1986), was low and consistent throughout the study and sampling site. Temporal variability for ice bacterial and background parameters was not pronounced over the $5 \mathrm{~d}$, suggesting that during stable weather conditions and excluding periods of fast biomass increase (ice algal blooms), a single ice sampling event can be temporally representative on weekly scales, a commonly used sampling interval in time series studies including biological parameters (Kaartokallio 2004, Mikkelsen et al. 2008, Søgaard et al. 2010). Pronounced vertical gradients, typical for sea ice and with highest values in the bottom ice, were seen in the salinity and calculated brine volume (Fig. 1) profiles as well as all bacterial parameters (Figs. 2 \& 3). Based on the NMDS analysis (Fig. 5), distance from interfaces (water-ice and air- 

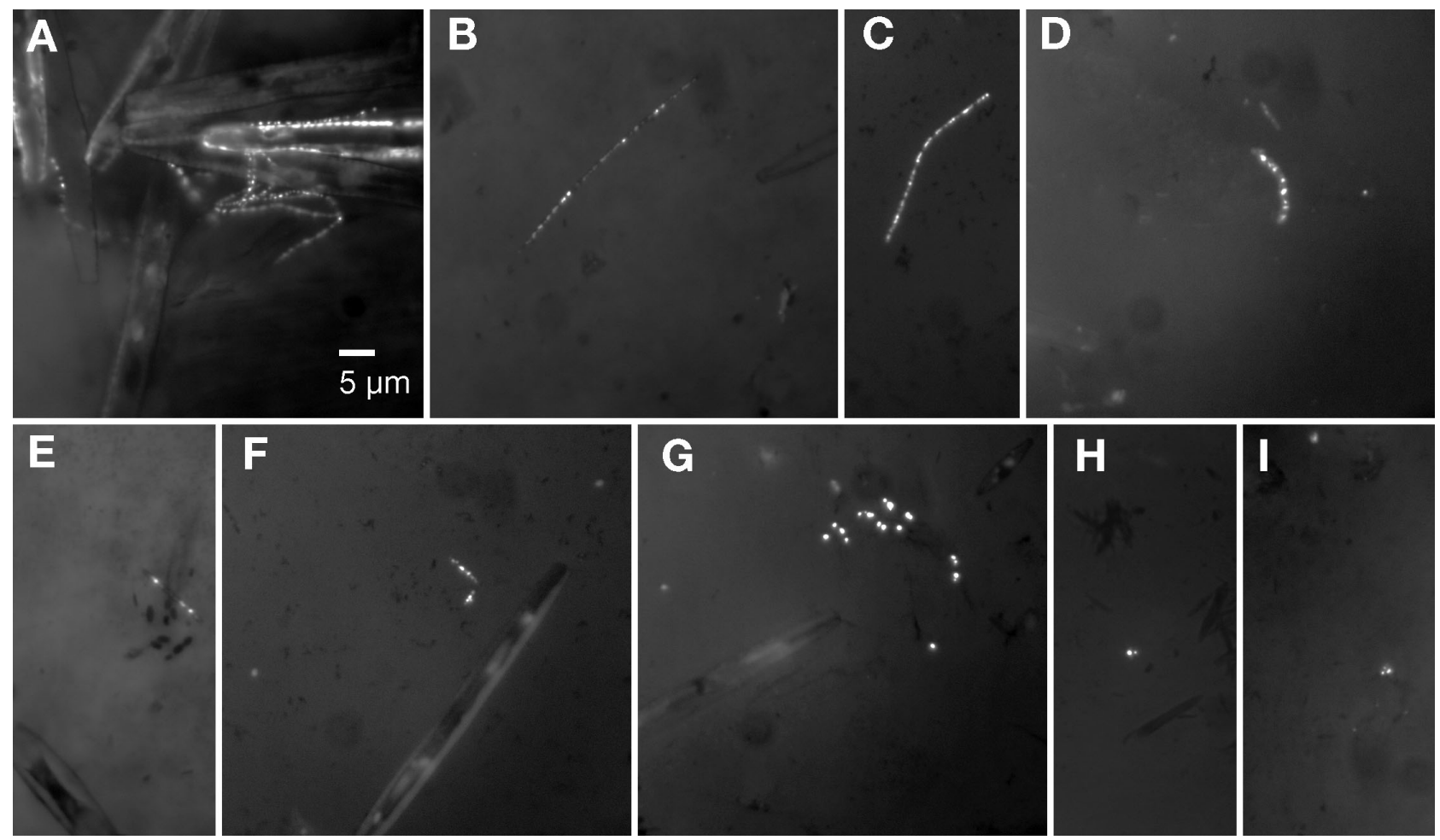

Fig. 6. Photomicrographs of Nile Blue A-stained bacterial cells containing polyhydroxyalkanoate granules. (A to C) Long filaments, (D) cells embedded in exopolymeric substance (EPS) matrix, (E) short filament, (F) long rods with multiple granules and ( $G$ to I) single and double granules. (A) to $(G)$ are from bottom ice sections, $(H)$ is from a brine sample and (I) is from an upper ice section

ice interface), which drive the steep environmental gradients, is a key parameter influencing the constitution and activity of the bacterial communities. The observed significant correlations (Fig. 5) between bacterial and environmental variables in NMDS illustrate the effect of environmental drivers on bacterial communities (salinity) or substrate availability produced by ice algae in bottom ice (i.e. DOM).

The proportion of HNA bacteria was higher in bottom ice than in upper ice, where LNA bacteria were dominant (Fig. 2). This observation is supportive of the findings of Collins et al. (2010), who found a dominance of oligotrophic bacterial lineages in upper sea ice layers. In under-ice water, the HNA:LNA ratio was more than 3 times lower than in bottom ice. This pattern is coherent with the assumption of greater carbon availability (as seen in the highest DOC and DON concentrations, Table 1) leading to higher abundance of HNA cells in bottom sections of ice. Also, the HNA bacterial cell size was larger in bottom ice. In the LNA populations, cell size was stable, indicating that the LNA bacteria indeed formed a natural distinct population of small cells (oligotrophs) and were not senescent large HNA bacteria with low nucleic acid content.
Simultaneous sampling of ice and brine provides insights into the partitioning between the brine fraction (that moves inside the brine channel system into the collection sackholes) and the total bacterial community within the ice matrix (that contains the entire bacterial population in ice including brines). We sampled brines at 40 and $50 \mathrm{~cm}$ depth, corresponding to the depth of the middle ice layers. The bacteria in brine (Tables $2 \& 3$ ) had a higher HNA:LNA ratio, and the cells were larger and more active than those in the whole ice fraction in middle ice layers, indicating that LNA bacteria were present in the upper ice horizons and did not move as readily with brines as HNA bacteria. The sackhole sampling technique used to extract brines is based on gravity drainage of brines and it may lead to under-representation of particulate material or bacteria associated with particles or trapped in EPS. Collins et al. (2010) discuss entrapment in EPS as a potential refuge for oligotrophic bacterial lineages in upper sea ice, which is in keeping with our results of higher proportions of LNA bacteria being retained within the ice matrix and not moving into brine sackholes by gravity.

The low concentrations of SRP and dissolved nitrogenous nutrients in the brines are evidence of 
their non-conservative partitioning relative to salinity within the brine channel system. Similar low concentrations of dissolved nutrients in brine have been reported form Antarctic sea ice (Becquevort et al. 2009). As $\mathrm{NO}_{3}{ }^{-}$and SRP concentrations in brine and bulk ice were low, and upper and middle ice layers were not biomass-rich, it can be assumed that the reason for similar concentrations was more likely entrapment of nutrients inside the brine channel system than release of nutrients from organisms or particulate matter during direct melting of bulk ice samples (c.f. Thomas et al. 1998). Becquevort et al. (2009) discuss entrapment within EPS as a potential cause for low nutrient concentrations in brines obtained by sackhole sampling, as in this study. For $\mathrm{NH}_{4}{ }^{+}$, direct incorporation into the ice matrix in addition to entrapment in EPS has been discussed by Zhou et al. (2013).

Although the bottom ice and under-ice water represent strongly diverging habitats by nature, the bacterial abundance, activities and cell properties in them were not significantly different (apart from the Leu incorporation and abundance of LNA cells), pointing to the influence of ice cover on waters immediately below the ice (0 $\mathrm{m}$ depth). This influence was likely mediated by ice melt and brine transporting sea ice bacteria across the ice-water interface (Long et al. 2012). Nguyen \& Maranger (2011) attribute the presence of large bacteria in under-ice water to the immediate proximity of ice in the western Arctic. Belzile et al. (2008) found a higher proportion of HNA bacteria under ice cover in spring compared to the open water season on the Beaufort Shelf, which also indicates the effect of ice on surface water bacterial communities.

In marine pelagic environments, saturation of both TdR and Leu incorporation is typically observed at 5 to $20 \mathrm{nmol} \mathrm{l^{-1 }}$ extracellular concentrations of labeled substrate (e.g. Fuhrman \& Azam 1982, Simon \& Azam 1989, Ducklow et al. 2000), whereas saturation levels for Leu in eutrophic or freshwater systems can be an order of magnitude higher (100 to $200 \mathrm{nmol} \mathrm{l}^{-1}$, Jørgensen 1992, van Looij \& Riemann 1993, Fischer \& Pusch 1999). In biofilms, saturating concentrations of Leu are in the range of 1000 to $2000 \mathrm{nmol} \mathrm{l}^{-1}$ (Fischer \& Pusch 1999, Törnblom \& Søndergaard 1999, Buesing \& Gessner 2003, Miranda et al. 2007) and 15 to $100 \mathrm{mmol} \mathrm{l}^{-1}$ in freshwater sediments (Tuominen 1995, Fischer \& Pusch 1999, Buesing \& Gessner 2003). We estimated high saturating concentrations (Fig. 4) for Leu in bottom ice crush samples (2100 nmol $\mathrm{l}^{-1}$ ) and brine originating from middle ice layers $\left(830 \mathrm{nmol} \mathrm{l}^{-1}\right)$, which were close to the biofilm satu- rating concentration range and clearly higher than in underlying water (230 $\mathrm{nmol} \mathrm{l}^{-1}$ ).

The use of Leu in bacterial production measurements in sea ice has been limited to a few studies in Antarctica and in the Baltic Sea, but these provide clear indications that Leu working concentrations used in oceanic waters are not adequate in sea ice. Grossmann \& Dieckmann (1994) used a $10 \mathrm{nmol} \mathrm{l}^{-1}$ Leu concentration for Weddell Sea brine samples and discuss possible Leu under-saturation as a reason for anomalous low Leu:TdR ratios. Guglielmo et al. (2000) and Pusceddu et al. (2008) also used a $10 \mathrm{nmol}$ $\mathrm{l}^{-1}$ Leu concentration for Antarctic fast ice crush samples and report extremely low or negligible bacterial carbon production compared to measured enzyme activities. However, they did not discuss the effect of under-saturation on their results. Studies done on Baltic Sea ice that have used 1 (Mock et al. 1997) to 2 orders of magnitude higher Leu saturating concentrations (Kaartokallio 2004, Kuosa \& Kaartokallio 2006, Kaartokallio et al. 2006, Piiparinen \& Kuosa 2011) do not report problems attributable to undersaturation.

The calculated isotope dilution in ice corresponds to the 80 to $100 \mathrm{nmol} \mathrm{l}^{-1}$ natural Leu concentration. This is in the same range as the measured $54 \mathrm{nmol} \mathrm{l}^{-1}$ Leu concentration in melted multiyear Arctic ice floe (Amon et al. 2001), but is perhaps unrealistically high for under-ice water. Based on the TdR saturation kinetics experiment, the TdR working concentrations used were still not saturating in ice and brine. However, the estimated degree of under-saturation was comparable in both Leu and TdR and we assume their ratios to be valid without correction to the saturating level.

Sea ice brine channels have been thought to resemble biofilm-like habitats, due to the high organism densities and large amounts of EPS creating gellike matrices (Krembs \& Deming 2008). Also, based on our results, Leu-saturating concentrations are close to those measured in aquatic biofilm systems, mostly freshwater and marine epi- and periphyton, where TdR and Leu methods have been routinely used. Nearly identical Leu saturating concentrations of 1 to $2 \mu \mathrm{mol} \mathrm{l}^{-1}$ over a wide range of biofilm systems and sea ice in this study point to a common underlying cause, possibly related to the bacterial adaptation to the biofilm environment.

We hypothesize that the variation in Leu incorporation saturating concentrations over 5 orders of magnitude in adjacent natural aquatic habitats (open water, biofilm, sediment) and the striking cross-system (fresh and marine waters, sea ice) stability in sat- 
urating concentrations might be explained by the bacterial communities' differential use of the primary and secondary Leu transport systems in these environments. Heterotrophic bacteria are known to possess bi- or multiphasic uptake systems for low molecular weight compounds, operating from nanomolar to millimolar concentration ranges (Azam \& Hodson 1981, Nissen et al. 1984, Fuhrman \& Ferguson 1986). Biphasic amino acid or Leu uptake/incorporation kinetics have been reported in marine waters (Unanue et al. 1999), bacterial culture experiments (Logan \& Fleury 1993) and freshwater submerged plant litter (Gillies et al. 2006). A bi- or multiphasic Leu incorporation kinetic pattern is consistent with the 3 known separate transport systems for branched-chain amino acids, or specifically Leu in gram-negative bacteria: 2 associated high-affinity primary ATP-binding cassette (ABC) transporter systems (LIV-1 and LS) and a secondary low-affinity $\mathrm{Na}^{+}$-dependent symporter system (LIV-2, Calvo \& Matthews 1994, Saier 2000). Both general types of amino acid transporter are also expressed by natural marine coastal bacterioplankton (Poretsky et al. 2010) as a response to DOC addition.

If the first 2 of the 3 distinct Leu saturation regimes mentioned above can be attributed to the ABC transporters LIV-1 and LS, the very much higher saturating concentrations of between 15 and $100 \mu \mathrm{mol} \mathrm{l}^{-1}$ possibly reflect the use of the secondary low-affinity Leu transport system LIV-2. This would be in keeping with the findings of Logan \& Fleury (1993), who reported a Leu saturation plateau between 1 and $1000 \mu \mathrm{mol} \mathrm{l} \mathrm{l}^{-1}$. ABC transporters are typically highly conserved, and a novel binding-protein-related homotropic autoregulation model for the maltose $A B C$ transporter described by Bao \& Duong (2012) may also be valid for Leu ABC transporters. Under the homotropic autoregulation model, saturating behavior is an inherent property of the transporter system and the actual saturating concentration dependent on the amount of transporters on the cell membrane, i.e. their expression level. Variation within the lower 2 regimes could thus possibly be due to community composition or expression levels of particular ABC transport systems.

As in aquatic biofilms, TdR-saturating concentrations in the ice were close to open-water values (Törnblom \& Søndergaard 1999, Pollard 2010) and in good agreement with earlier results from Arctic ice-associated waters (Garneau et al. 2008). TdR uptake activity in gram-negative bacteria is regulated by immediate phosphorylation inside the cell (Mizushima et al. 1997), resulting in non-saturated kinetics at higher concentrations (Logan \& Fleury 1993). Use of TdR concentrations of $10 \mathrm{nmol} \mathrm{l}^{-1}$ in Antarctic sea ice have produced realistic production estimates (Grossmann \& Dieckmann 1994, Helmke \& Weyland 1995). For $\mathrm{TdR}$, under-saturation at $20 \mathrm{nmol}^{-1}$ (ratios added to $V_{\max 90} 1.6$ to 1.8 ) in ice and brines point to a need for higher TdR working concentrations in ice and brines than used in cold polar surface waters.

Unfortunately, our saturation kinetics experiment did not extend to a higher range of TdR concentrations, or lower range of Leu concentrations, but were initially designed to validate the working concentrations used. Thus, we cannot verify the existence of bior multiphasic TdR or Leu incorporation kinetics in sea ice but point to the existence of differing saturating concentrations across the sample types and tracers used. Our results suggest that in sea ice bacterial production measurements, Leu concentrations typical for biofilms, rather than oceanic seawater, should be used, and saturating concentrations for both TdR and Leu should be tested over a broad range.

The Leu:TdR ratio is a widely employed indicator for physiological or metabolic status of bacterial communities, since it reflects the ratio of the 2 major basic metabolic functions in bacteria: protein and DNA synthesis. In a range of aquatic systems, the Leu:TdR ratios typically vary between 5 and 70, and departure from balanced growth is indicated by increased ratios (Chin-Leo \& Kirchman 1990, Kirchman 1992, Shiah \& Ducklow 1997). Leu:TdR ratios presented in this study were generally high and showed a consistent pattern in ice over the entire study period: ratios were highest in bottom ice, elevated in upper ice sections and lowest in the middle ice section. The obvious explanations for high Leu:TdR ratios in the upper and bottom ice are unbalanced growth (i.e. bacteria increasing their biomass without DNA synthesis) or non-specific incorporation of Leu into non-protein macromolecules. Uncoupling between Leu and TdR has also been reported in coastal marine epiphytic biofilms, where increasing Leu incorporation was positively correlated with the age of the biofilm (Törnblom \& Søndergaard 1999).

To estimate the validity of divergent Leu- and TdRbased bacterial production estimates, we calculated the production estimate based on previously published data for oxygen exchange at the ice-water interface obtained during the same campaign at the same site (Long et al. 2012), which gave a net mean oxygen flux into bottom ice of $-2.13 \mathrm{mmol} \mathrm{O}_{2} \mathrm{~m}^{-2} \mathrm{~d}^{-1}$ and an average gross primary productivity equal to production of $0.69 \mathrm{mmol} \mathrm{O}_{2} \mathrm{~m}^{-2} \mathrm{~d}^{-1}$ (assuming a 1:1 $\mathrm{C}: \mathrm{O}_{2}$ ratio). Primary productivity was mostly confined 
to the lowermost ice layers (Søgaard et al. 2013). Our mean bacterial respiration estimates for bottom ice, 0.52 and $3.37 \mathrm{mmol} \mathrm{O}_{2} \mathrm{~m}^{-2} \mathrm{~d}^{-1}$ for TdR and Leu, respectively, are in the same range as the oxygen exchange values presented by Long et al. (2012), suggesting that bacterial respiration alone was close to the observed oxygen fluxes. However, bacterial respiration accounts for only a part of the community respiration. If bacterial respiration is assumed to be $44 \%$ of community respiration (Robinson 2008, Kirchman et al. 2009, Nguyen \& Maranger 2011), TdR and Leu incorporation results provide an estimated community respiration of 1.18 and $8.45 \mathrm{mmol}$ $\mathrm{O}_{2} \mathrm{~m}^{-2} \mathrm{~d}^{-1}$, respectively, the latter being unrealistically high. If estimated tracer under-saturation in ice is taken into account, the TdR community respiration estimate is $1.89 \mathrm{mmol} \mathrm{O}_{2} \mathrm{~m}^{-2} \mathrm{~d}^{-1}$, being close to the oxygen flux estimate of Long et al. (2012).

The saturation-level-corrected estimate for Leu is almost an order of magnitude too high, a difference unexplained by the conversion factors used. The high Leu incorporation implies that the incorporated Leu is not only ending up in the protein fraction. Mock et al. (1997), working on Baltic Sea brines, found 2-fold lower Leu incorporation after hot TCA extraction as compared to cold TCA extraction, which also points to non-protein incorporation. One possible route for non-protein Leu incorporation is the inclusion into PHA granules via the branched-chain amino acid degradation pathway to the important PHA precursor acetyl-coenzyme A (CoA). The full Leu degradation pathway is known to be present in some ice-inhabiting proteobacterial genera (Kazakov et al. 2009). A key enzyme of this degradation pathway, methylcrotonylCoA carboxylase, has been recently associated with high dark bicarbonate uptake and possible Leu degradation by natural Arctic surface water Gammaproteobacteria (Alonso-Sáez et al. 2010). Leu usage for intracellular polymer production has also been proposed by Ducklow \& Yager (2007) to explain rapid Leu turnover in cold polynya surface waters.

PHAs are highly reduced, structurally simple macromolecules that are deposited into water-insoluble inclusion bodies within bacterial cells (Anderson \& Dawes 1990, Madison \& Huisman 1999) and can be used as carbon and energy storage and to alleviate oxidative stress (Ayub et al. 2009). The regulation of PHA production may be directly linked to biofilm formation (Campisano et al. 2008, Tribelli et al. 2012). PHA-producing bacteria in marine habitats have so far been mostly found in sediments or biofilms (Koller et al. 2011), although 2 species of the genus Oceanicola (Alphaproteobacteria), isolated from seawater at the Bermuda-Atlantic Time-series Study Site, have been shown to produce intracellular PHA granules in culture (Cho \& Giovannoni 2004). We found various bacterial morphotypes containing putative PHA granules in the bottom ice samples (Fig. 6), suggesting actual PHA production by multiple sea ice bacterial species beyond the only currently known (by genomic traits) sea ice-inhabiting PHA producer Colwellia psychrerythrea (Methé et al. 2005). A hypothetical ecological function for PHA production by sea ice bacteria could be storage of excess carbon (Pomeroy \& Wiebe 2001), thereby enhancing their survival in the more dilute planktic environment following ice melt.

\section{CONCLUSIONS}

Our results demonstrate small diel variability in bacterial parameters and suggest that a weekly sampling strategy can be temporally representative in sea ice bacteria monitoring studies in subarctic sea ice. Under climatically unstable conditions (e.g. ice warming introducing melting and brine instability) or during periods of rapid biomass growth in spring, more frequent sampling may be needed to adequately cover the variability (Maranger et al. 1994, Riedel et al. 2007).

Our results support earlier views of sea ice habitats acting as biofilm-like systems rather than being analogous to open-water systems. We found biofilmlike saturating concentrations for Leu incorporation in bottom sea ice horizons and we suggest that it would be pertinent for future investigations into sea ice and adjacent permanently cold waters to test a wide concentration range and establish saturating concentrations.

Bacterial cell properties as revealed by flow cytometry imply a distribution of copiotrophic and oligotrophic ecotypes in ice and underlying water, reflecting DOM distribution, and show that flow cytometry is a useful tool for studying sea ice bacteria. We have provided evidence that subarctic sea ice bacteria in the natural environment can produce PHA. Taking into account the vast areal coverage of sea ice, our results suggest that there may be a significantly wider spatial and geographical occurrence of natural bacterial PHA production in marine environments than previously acknowledged. Furthermore, our results point to the influence of ice cover on the underlying water bacterial community and the need to consider icecovered surface waters as a habitat for bacteria that is quite distinct from open marine waters not influenced by sea ice. 
Acknowledgements. The study received financial support from the Greenland Climate Research Centre, and D.H.S. was financially supported by the commission for scientific Research in Greenland (KVUG). D.N.T. and L.N. are grateful to the Royal Society and NERC for support for their participation in the work. H.K. and D.N.T. are also grateful to the Academy of Finland (FiDiPro programme) for their support. S.R. acknowledges the support of the Canada Excellence Research Chair (CERC) program.

\section{LITERATURE CITED}

Alonso-Sáez L, Galand PE, Casamayor EO, Pedrós-Alió C, Bertilsson S (2010) High bicarbonate assimilation in the dark by Arctic bacteria. ISME J 4:1581-1590

Amon RMW, Fitznar HP, Benner R (2001) Linkages among the bioreactivity, chemical composition, and diagenetic state of marine dissolved organic matter. Limnol Oceanogr 46: 287-297

Anderson AJ, Dawes EA (1990) Occurrence, metabolism, metabolic role, and industrial uses of bacterial polyhydroxyalkanoate. Microbiol Rev 54:450-472

> Ayo B, Unanue M, Azua I, Gorsky G, Turley C, Iriberri J (2001) Kinetics of glucose and amino acid uptake by attached and free-living marine bacteria in oligotrophic waters. Mar Biol 138:1071-1076

Ayub ND, Tribelli PM, López NI (2009) Polyhydroxyalkanoates are essential for maintenance of redox state in the Antarctic bacterium Pseudomonas sp. 14-3 during low temperature adaptation. Extremophiles 13:59-66

> Azam F, Hodson RE (1981) Multiphasic kinetics for D-glucose uptake by assemblages of natural marine bacteria. Mar Ecol Prog Ser 6:213-222

Bao H, Duong F (2012) Discovery of an auto-regulation mechanism for the maltose ABC transporter MalFGK2. PLoS ONE 7:e34836

Becquevort S, Dumont I, Tison J-L, Lannuzel D, Sauvee M-L, Chou L, Schoemann V (2009) Biogeochemistry and microbial community composition in sea ice and underlying seawater off East Antarctica during early spring. Polar Biol 32: 879-895

Belzile C, Brugel S, Nozais C, Gratton Y, Demers S (2008) Variations of the abundance and nucleic acid content of heterotrophic bacteria in Beaufort Shelf waters during winter and spring. J Mar Syst 74:946-956

Bjørnsen PK, Kuparinen J (1991) Determination of bacterioplankton biomass, net production and growth efficiency in the Southern Ocean. Mar Ecol Prog Ser 71:185-194

> Buesing N, Gessner MO (2003) Incorporation of radiolabeled leucine into protein to estimate bacterial production in plant litter, sediment, epiphytic biofilms, and water samples. Microb Ecol 45:291-301

Calvo JM, Matthews RG (1994) The leucine-responsive regulatory protein, a global regulator of metabolism in Escherichia coli. Microbiol Rev 58:466-490

> Campisano A, Overhage J, Rehm BHA (2008) The polyhydroxyalkanoate biosynthesis genes are differentially regulated in planktonic- and biofilm-grown Pseudomonas aeruginosa. J Biotechnol 133:442-452

> Chin-Leo G, Kirchman DL (1990) Unbalanced growth in natural assemblages of marine bacterioplankton. Mar Ecol Prog Ser 63:1-8

Cho JC, Giovannoni SJ (2004) Oceanicola granulosus gen. nov., sp. nov. and Oceanicola batsensis sp. nov., poly- $\beta$ hydroxybutyrate-producing marine bacteria in the order 'Rhodobacterales'. Int J Syst Evol Microbiol 54:1129-1136
Collins RE, Rocap G, Deming JW (2010) Persistence of bacterial and archaeal communities in sea ice through an Arctic winter. Environ Microbiol 12:1828-1841

Cox GFN, Weeks WF (1983) Equations for determining the gas and brine volumes in sea ice samples. J Glaciol 29: 306-316

Deming JW (2010) Sea ice bacteria and viruses. In: Thomas DN, Dieckmann GS (eds) Sea ice, 2nd edn. Wiley-Blackwell, Oxford, p 247-282

Ducklow HW (2003) Seasonal production and bacterial utilization of DOC in the Ross Sea, Antarctica. Antarctic Res Ser 78:143-158

Ducklow HW, Yager PL (2007) Pelagic bacterial processes in Polynyas. In: Smith WO Jr., Barber DG (eds) Polynyas: Windows into polar oceans. Elsevier Oceanography Series 74, Elsevier BV, p 323-361

Ducklow H, Dickson M, Kirchman D, Steward G, Orchardo J, Marra J, Azam F (2000) Constraining bacterial production, conversion efficiency and respiration in the Ross Sea, Antarctica, January-February, 1997. Deep-Sea Res II 47: 3227-3247

Fischer H, Pusch M (1999) Use of the $\left[{ }^{14} \mathrm{C}\right]$ leucine incorporation technique to measure bacterial production in river sediments and the epiphyton. Appl Environ Microbiol 65: 4411-4418

Fransson A, Chierici M, Yager PL, Smith WO Jr. (2011) Antarctic sea ice carbon dioxide system and controls. J Geophys Res 116(C12), C12035, doi:10.1029/2010JC006844

Fuhrman JA, Azam F (1980) Bacterioplankton secondary production estimates for coastal waters of British Columbia, Antarctica, and California. Appl Environ Microbiol 39: 1085-1095

Fuhrman JA, Azam F (1982) Thymidine incorporation as a measure of heterotrophic bacterioplankton production in marine surface waters: evaluation and field results. Mar Biol 66:109-120

Fuhrman JA, Ferguson RL (1986) Nanomolar concentrations and rapid turnover of dissolved free amino acids in seawater: agreement between chemical and microbiological measurements. Mar Ecol Prog Ser 33:237-242

> Garneau ME, Roy S, Lovejoy C, Gratton Y, Vincent WF (2008) Seasonal dynamics of bacterial biomass and production in a coastal arctic ecosystem: Franklin Bay, western Canadian Arctic. J Geophys Res 113(C7), C07S91, doi:10.1029/ 2007JC004281

Gasol JM, del Giorgio PA (2000) Using flow cytometry for counting natural planktonic bacteria and understanding the structure of planktonic bacterial communities. Sci Mar 64:197-224

Gasol JM, Zweifel UL, Peters F, Fuhrman JA, Hagström ^ (1999) Significance of size and nucleic acid content heterogeneity as measured by flow cytometry in natural planktonic bacteria. Appl Environ Microbiol 65:4475-4483

Gillies JE, Kuehn KA, Francoeur SN, Neely RK (2006) Application of the $\left[{ }^{3} \mathrm{H}\right]$ leucine incorporation technique for quantification of bacterial secondary production associated with decaying wetland plant litter. Appl Environ Microbiol 72:5948-5956

> Gosselin M, Legendre L, Therriault J-C, Demers S, Rochet M (1986) Physical control of the horizontal patchiness of seaice microalgae. Mar Ecol Prog Ser 29:289-298

Grasshoff K, Ehrhardt M, Kremling K (1983) Methods of seawater analysis, 2nd edn. Verlag Chemie, Wienheim

Grossmann S, Dieckmann GS (1994) Bacterial standing stock, activity, and carbon production during formation and growth of sea ice in the Weddell Sea, Antarctica. Appl Environ Microbiol 60:2746-2753 
Guglielmo L, Carrada G, Catalano G, Dell'Anno A and others (2000) Structural and functional properties of sympagic communities in the annual sea ice at Terra Nova Bay (Ross Sea, Antarctica). Polar Biol 23:137-146

> Hales B, van Greer A, Takahashi T (2004) High-frequency measurements of seawater chemistry: Flow-injection analysis of macronutrients. Limnol Oceanogr Methods 2: 91-101

> Helmke E, Weyland H (1995) Bacteria in sea ice and underlying water of the eastern Weddell Sea in midwinter. Mar Ecol Prog Ser 117:269-287

Holmes RM, Aminot A, Kerouel R, Hocker BA, Peterson BJ (1999) A simple and precise method for measuring ammonium in marine and fresh water. Can J Fish Aquat Sci 56: 1801-1808

Ishige T, Tani A, Sakai Y, Kato N (2003) Wax ester production by bacteria. Curr Opin Microbiol 6:244-250

> Jørgensen NOG (1992) Incorporation of $\left[{ }^{3} \mathrm{H}\right]$ leucine and $\left[{ }^{3} \mathrm{H}\right]$ valine into protein of freshwater bacteria: Uptake kinetics and intracellular isotope dilution. Appl Environ Microbiol 58:3638-3646

> Junge K, Imhoff F, Staley T, Deming JW (2002) Phylogenetic diversity of numerically important Arctic sea-ice bacteria cultured at subzero temperature. Microb Ecol 43:315-328

Kaartokallio H (2004) Food web components, and physical and chemical properties of Baltic Sea ice. Mar Ecol Prog Ser 273:49-63

Kaartokallio H, Kuosa H, Thomas DN, Granskog MA, Kivi K (2006) Biomass, composition and activity of organism assemblages along a salinity gradient in sea ice subjected to river discharge in the Baltic Sea. Polar Biol 30:183-197

Kaartokallio H, Tuomainen J, Kuosa H, Kuparinen J, Martikainen PJ, Servomaa K (2008) Succession of sea-ice bacterial communities in the Baltic Sea fast ice. Polar Biol 31: 783-793

Kazakov AE, Rodionov DA, Alm E, Arkin AP, Dubchak I, Gelfand MS (2009) Comparative genomics of regulation of fatty acid and branched-chain amino acid utilization in Proteobacteria. J Bacteriol 191:52-64

Kirchman DL (1992) Incorporation of thymidine and leucine in the subarctic Pacific: application to estimating bacterial production. Mar Ecol Prog Ser 82:301-309

Kirchman D, K'nees E, Hodson R (1985) Leucine incorporation and its potential as a measure of protein synthesis by bacteria in natural aquatic systems. Appl Environ Microbiol 49:599-607

Kirchman DL, Hill V, Cottrell MT, Gradinger R, Malmstrom RR, Parker A (2009) Standing stocks, production, and respiration of phytoplankton and heterotrophic bacteria in the western Arctic Ocean. Deep-Sea Res II 56:1237-1248

Koller M, Gasser I, Schmid F, Berg G (2011) Linking ecology with economy: Insights into polyhydroxyalkanoate-producing microorganisms. Eng Life Sci 11:222-237

Kottmeier S, Grossi SM, Sullivan CW (1987) Sea ice microbial communities. VIII. Bacterial production in annual sea ice of McMurdo Sound, Antarctica. Mar Ecol Prog Ser 35: 175-186

Krembs C, Deming JW (2008) The role of exopolymers in microbial adaptation to sea ice. In: Margesin R, Schinner F, Marx J-C, Gerday C (eds) Psychrophiles: from biodiversity to biotechnology. Springer-Verlag, Heidelberg, p 247-264

Krembs C, Eicken H, Deming JW (2011) Exopolymer alteration of physical properties of sea ice and implications for ice habitability and biogeochemistry in a warmer Arctic. Proc Natl Acad Sci USA 108:3653-3658

- Kroon H (1993) Determination of nitrogen in water: comparison of continuous flow method with on-line UV digestion with the original Kjeldahl method. Anal Chim Acta 276: 287-293

Kuosa H, Kaartokallio H (2006) Experimental evidence on nutrient and substrate limitation of Baltic Sea sea-ice algae and bacteria. Hydrobiologia 554:1-10

Kuparinen J, Autio R, Kaartokallio H (2011) Sea ice bacterial growth rate, growth efficiency and preference for inorganic nitrogen sources in the Baltic Sea. Polar Biol 34: 1361-1373

Lebaron P, Servais P, Agogué H, Courties C, Joux F (2001) Does the high nucleic-acid content of individual bacterial cells allow to discriminate active cells in aquatic systems? Appl Environ Microbiol 67:1775-1782

> Logan BE, Fleury RC (1993) Multiphasic kinetics can be an artifact of the assumption of saturable kinetics for microorganisms. Mar Ecol Prog Ser 102:115-124

Long $\mathrm{MH}$, Koopmans D, Berg P, Rysgaard S, Glud RN, Søgaard DH (2012) Oxygen exchange and ice melt measured at the ice-water interface by eddy correlation. Biogeosciences 9:1957-1967

Madison LL, Huisman GW (1999) Metabolic engineering of poly(3-hydroxyalkanoates): from DNA to plastic. Microbiol Mol Biol Rev 63:21-53

Maranger R, Bird DF, Juniper SK (1994) Viral and bacterial dynamics in Arctic sea ice during the spring algal bloom near Resolute, N.W.T., Canada. Mar Ecol Prog Ser 111:121-127

> Martin A, Anderson MJ, Thorn C, Davy SK, Ryan KG (2011) Response of sea-ice microbial communities to environmental disturbance: an in situ transplant experiment in the Antarctic. Mar Ecol Prog Ser 424:25-37

> Mary I, Heywood JL, Fuchs BM, Amann R, Tarran GA, Burkill PH, Zubkov MV (2006) SAR11 dominance among metabolically active low nucleic acid bacterioplankton in surface waters along an Atlantic meridional transect. Aquat Microb Ecol 45:107-113

Methé BA, Nelson KE, Deming JW, Momen B and others (2005). The psychrophilic lifestyle as revealed by the genome sequence of Colwellia psychrerythraea $34 \mathrm{H}$ through genomic and proteomic analyses. Proc Natl Acad Sci USA 102:10913-10918

> Middelboe M, Glud RN, Sejr MK (2012) Bacterial carbon cycling in a subarctic fjord: A seasonal study on microbial activity, growth efficiency, and virus-induced mortality in Kobbefjord, Greenland. Limnol Oceanogr 57:1732-1742

Mikkelsen DM, Rysgaard S, Glud RN (2008) Microalgal composition and primary production in Arctic sea ice: a seasonal study from Kobbefjord (Kangerluarsunnguaq), West Greenland. Mar Ecol Prog Ser 368:65-74

Miranda MR, Guimarães JRD, Coelho-Souza AS (2007) $\left[{ }^{3} \mathrm{H}\right]$ Leucine incorporation method as a tool to measure secondary production by periphytic bacteria associated to the roots of floating aquatic macrophyte. J Microbiol Methods 71:23-31

Mizushima T, Yokoyama K, Mima S, Tsuchiya T, Sekimizu K (1997) Inhibition of thymidine transport in dnaA mutants of Escherichia coli. J Biol Chem 272:21195-21200

> Mock T, Meiners KM, Giesenhagen HC (1997) Bacteria in sea ice and underlying brackish water at 54 $26^{\prime} 50^{\prime \prime} \mathrm{N}$ (Baltic Sea, Kiel Bight). Mar Ecol Prog Ser 158:23-40

Morán XAG, Bode A, Ángel Suárez L, Nogueira E (2007) Assessing the relevance of nucleic acid content as an indicator of marine bacterial activity. Aquat Microb Ecol 46: $141-152$

Mundy CJ, Gosselin M, Ehn JK, Belzile C and others (2011) Characteristics of two distinct high-light acclimated algal communities during advanced stages of sea ice melt. Polar Biol 34:1869-1896 
Nguyen D, Maranger R (2011) Respiration and bacterial carbon dynamics in Arctic sea ice. Polar Biol 34:1843-1855

Nissen H, Nissen P, Azam F (1984) Multiphasic uptake of Dglucose by an oligotrophic marine bacterium. Mar Ecol Prog Ser 16:155-160

Oksanen JF, Blanchet $G$, Kindt $R$, Legendre $P$ and others (2012) Vegan: Community Ecology Package. R package version 2.0-5. CRAN.R-project.org/package=vegan

Ostle AG, Holt JG (1982) Nile blue A as a fluorescent stain for poly-beta-hydroxybutyrate. Appl Environ Microbiol 44: 238-241

Petrich C, Eicken H (2010) Growth, structure and properties of sea ice. In: Thomas DN, Dieckmann GS (eds) Sea ice, 2nd edn. Wiley-Blackwell, Oxford, p 23-78

Piiparinen J, Kuosa H (2011) Impact of UVA radiation on algae and bacteria in Baltic Sea ice. Aquat Microb Ecol 63: 75-87

> Pollard PC (2010) Bacterial activity in plant (Schoenoplectus validus) biofilms of constructed wetlands. Water Res 44 : 5939-5948

Pomeroy LR, Wiebe WJ (2001) Temperature and substrates as interactive limiting factors for marine heterotrophic bacteria. Aquat Microb Ecol 23:187-204

Poretsky RS, Sun S, Mou X, Moran MA (2010) Transporter genes expressed by coastal bacterioplankton in response to dissolved organic carbon. Environ Microbiol 12: 616-627

Pusceddu A, Dell'Anno A, Vezzulli L, Fabiano M and others (2008) Microbial loop malfunctioning in the annual sea ice at Terra Nova Bay (Antarctica). Polar Biol 32:337-346

Qian J, Mopper K (1996) High performance high temperature combustion total organic carbon analyzer. Anal Chem 68: 3090-3097

R Development Core Team (2011) R: A language and environment for statistical computing. R Foundation for Statistical Computing, Vienna

Rappé MS, Connon SA, Vergin KL, Giovannoni SJ (2002) Cultivation of the ubiquitous SAR11 marine bacterioplankton clade. Nature 418:630-633

Riedel A, Michel C, Gosselin M (2007) Grazing of large-sized bacteria by sea-ice heterotrophic protists on the Mackenzie Shelf during the winter-spring transition. Aquat Microb Ecol 50:25-38

Rivkin RB, Legendre L (2001) Biogenic carbon cycling in the upper ocean: effects of microbial respiration. Science 291: 2398-2400

Robinson C (2008) Heterotrophic bacterial respiration. In: Kirchman DL (ed) Microbial ecology of the oceans. WileyBlackwell, Oxford, p 299-334

Saier MH (2000) Families of transmembrane transporters selective for amino acids and their derivatives. Microbiology 146:1775-1795

Shiah FK, Ducklow HW (1997) Bacterioplankton growth responses to temperature and chlorophyll variations in estuaries measured by thymidine:leucine incorporation ratio. Aquat Microb Ecol 13:151-159

Simon M, Azam F (1989) Protein content and protein synthesis rates of planktonic marine bacteria. Mar Ecol Prog Ser 51:201-213

Smith REH, Clement P (1990) Heterotrophic activity and bac-

Editorial responsibility: Hugh Ducklow,

Woods Hole, Massachusetts, USA terial productivity in assemblages of microbes from sea ice in the high Arctic. Polar Biol 10:351-357

Søgaard DH, Kristensen M, Rysgaard S, Glud RN, Hansen PJ, Hilligsøe KM (2010) Autotrophic and heterotrophic activity in Arctic first-year sea ice: seasonal study from Malene Bight, SW Greenland. Mar Ecol Prog Ser 419:31-45

Søgaard DH, Thomas DN, Rysgaard S, Glud RN and others (2013) The relative contributions of biological and abiotic processes to the carbon dynamics in subarctic sea ice. Polar Biol. doi:10.1007/s00300-013-1396-3

> Thomas DN, Dieckmann GS (2002) Antarctic sea ice-a habitat for extremophiles. Science 295:641-644

Thomas DN, Dieckmann GS (eds) (2010) Sea ice, 2nd edn. Wiley-Blackwell, Oxford

Thomas DN, Lara RJ, Haas C, Schnack-Schiel SB and others (1998) Biological soup within decaying summer sea ice in the Amundsen Sea, Antarctica. In: Lizotte M, Arrigo K (eds) Antarctic sea ice biological processes, interactions and variability. Antarctic Res Ser 73:161-171

Thomas DN, Papadimitriou S, Michel C (2010) The biogeochemistry of sea ice. In: Thomas DN, Dieckmann GS (eds) Sea ice, 2nd edn. Wiley-Blackwell, Oxford, p 425-467

Törnblom E, Søndergaard M (1999) Seasonal dynamics of bacterial biomass and production on eelgrass Zostera marina leaves. Mar Ecol Prog Ser 179:231-240

Tribelli PM, Di Martino C, López NI, Raiger Iustman LJ (2012) Biofilm lifestyle enhances diesel bioremediation and biosurfactant production in the Antarctic polyhydroxyalkanoate producer Pseudomonas extremaustralis. Biodegradation 23:645-651

Tuominen L (1995) Comparison of leucine uptake methods and a thymidine incorporation method for measuring bacterial activity in sediment. J Microbiol Methods 24:125-134

Unanue M, Ayo B, Agis M, Slezak D, Herndl G, Iriberri J (1999) Ectoenzymatic activity and uptake of monomers in marine bacterioplankton described by a biphasic kinetic model. Microb Ecol 37:36-48

Underwood GJC, Fietz S, Papadimitriou S, Thomas DN, Dieckmann GS (2010) Distribution and composition of dissolved extracellular polymeric substances (EPS) in Antarctic sea ice. Mar Ecol Prog Ser 404:1-19

Underwood GJC, Aslam SN, Michel C, Niemi A and others (2013). Broad-scale predictability of carbohydrates and exopolymers in Antarctic and Arctic sea ice. Proc Natl Acad Sci USA 110:15734-15739

van Looij A, Riemann B (1993) Measurements of bacterial production in coastal marine environments using leucine: application of a kinetic approach to correct for isotope dilution. Mar Ecol Prog Ser 102:97-104

Wältermann M, Steinbüchel A (2005) Neutral lipid bodies in prokaryotes: recent insights into structure, formation, and relationship to eukaryotic lipid deposits. J Bacteriol 187: 3607-3619

Wang Y, Hammes F, Boon N, Chami M, Egli T (2009) Isolation and characterization of low nucleic acid (LNA)-content bacteria. ISME J 3:889-902

Zhou J, Delille B, Eicken H, Vancoppenolle M and others (2013) Physical and biogeochemical properties in landfast sea ice (Barrow, Alaska): Insights on brine and gas dynamics across seasons. J Geophys Res Oceans 118:3172-3189

Submitted: April 22, 2013; Accepted: September 23, 2013 Proofs received from author(s): November 15, 2013 